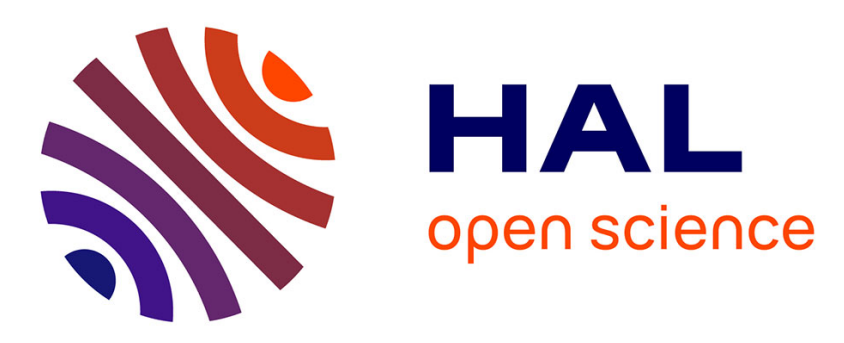

\title{
Studies on the Reduction of [(C5Me5)2Mo2O5] in Methanol/Water/Acetate Solutions by On-Line Electrochemical Flowcell and Electrospray Mass Spectrometry
}

Jenny Gun, Alexandre Modestov, Ovadia Lev, Dirk Saurenz, Mikhail a. Vorotyntsev, Rinaldo Poli

\section{To cite this version:}

Jenny Gun, Alexandre Modestov, Ovadia Lev, Dirk Saurenz, Mikhail a. Vorotyntsev, et al.. Studies on the Reduction of [(C5Me5)2Mo2O5] in Methanol/Water/Acetate Solutions by On-Line Electrochemical Flowcell and Electrospray Mass Spectrometry. European Journal of Inorganic Chemistry, 2003, 2003 (3), pp.482-492. 10.1002/ejic.200390068 . hal-03283737

\section{HAL Id: hal-03283737 https://hal.science/hal-03283737}

Submitted on 19 Jul 2021

HAL is a multi-disciplinary open access archive for the deposit and dissemination of scientific research documents, whether they are published or not. The documents may come from teaching and research institutions in France or abroad, or from public or private research centers.
L'archive ouverte pluridisciplinaire HAL, est destinée au dépôt et à la diffusion de documents scientifiques de niveau recherche, publiés ou non, émanant des établissements d'enseignement et de recherche français ou étrangers, des laboratoires publics ou privés. 


\section{European Journal of Inorganic Chemistry}

\section{Studies of the reduction of $\left(\mathrm{C}_{5} \mathrm{Me}_{5}\right)_{2} \mathrm{Mo}_{2} \mathrm{O}_{5}$ in Methanol - Water -} Acetate Solutions by On-Line Electrochemical Flowcell and Electrospray Mass Spectrometry.

Jenny Gun, ${ }^{*[a]}$ Alexandre Modestov, ${ }^{[\mathrm{a}]}$ Ovadia Lev, ${ }^{[\mathrm{a}]}$ Dirk Saurenz ${ }_{9}^{[\mathrm{b}]}$ Mikhail Vorotyntsev, ${ }^{[b]}$ and Rinaldo Poli* ${ }^{[b]}$

${ }^{[a]}$ Div. of Environmental Sciences, Fredy and Nadine Hermann School of Applied Science, The Hebrew University of Jerusalem, Jerusalem, Israel

Fax: 972-2-6586155

E-mail: gunjen@pob.huji.ac.il

${ }^{[b]}$ Laboratoire de Synthèse et d'Electrosynthèse Organométalliques, Faculté des Sciences "Gabriel", Université de Bourgogne, 6 Boulevard Gabriel, 21000 Dijon, France

Fax: $+33-380393720$

E-mail:poli@u-bouregogne.fr

Received (will be filled in by the editorial staff)

Molybdenum/ Oxo ligands / Cyclopentadienyl ligands / Electrospray ionisation mass spectrometry / Electrochemistry 
The complex $\mathrm{Cp}_{2}{ }_{2} \mathrm{Mo}_{2} \mathrm{O}_{5}\left(\mathrm{Cp}^{*}=\eta^{5}-\mathrm{C}_{5} \mathrm{Me}_{5}\right)$ and its electrochemical reduction products in acetic acid/acetate-buffered ( $\mathrm{pH}$ 4.0) water-methanol solutions were investigated by combined electrochemical (EC) flow cell and on-line electrospray ionization mass spectrometry (ESI-MS). Mono-, di-, tri- and tetranuclear organometallic molybdenum oxides have been identified in the starting solution. The effect of the relevant ESI-MS parameters (ionic mode, heated capillary voltage and heated capillary temperature) and of the concentration on the observed distribution of ions in the mass spectrometer was studied in order to minimize side reactions in the ESI chamber. It was verified that reduction in the ESI-MS is undetectable under open circuit conditions. The online electrochemical study revealed the potential-dependent formation of previously unknown mono-, bi-, tri- and tetranuclear $\mathrm{Mo}^{\mathrm{V}}, \mathrm{Mo}^{\mathrm{IV}}$, and mixed-valence complexes. The compounds were identified on the basis of their characteristic isotope pattern and their ion trap $\mathrm{MS}^{\mathrm{n}}$ fragmentation. The observed formation potentials reflect the higher stability of the multinuclear species compared to the mononuclear ones within the same oxidation state. 


\section{Introduction}

The rapid development and eventual commercialization of the Electrospray Ionization Mass Spectrometers (ESI-MS) in the eighties and nineties has opened the door to the determination of nonvolatile inorganic, organic and organometallic compounds by mass spectrometry. ${ }^{1,2}$ ESI-MS is an atmospheric pressure technique that uses an electrostatic sprayer to transfer ionic solutes from the sample solution to the gas phase. ${ }^{3,4}$ The ESI-MS technique is gradually becoming a valuable tool for the investigation of organometallic compounds in protic as well as in aprotic solvents ${ }^{4}$ and has proven especially useful in combination with the investigations of redox processes, particularly reduction processes.

Electrochemical methods are the method of choice for obtaining reduced organometallic compounds since potential dependent information can be readily obtained, reversibility is easily checked, and complexation by the chemical reducing agents or their byproducts is minimized. Bond et al. have made extensive use of ESI-MS for the understanding of complex electrochemical transformations of organometallic compounds such as the reductions of cis$\left(\mathrm{Et}_{2} \text {-dcbpy }\right)_{2} \mathrm{RuX}_{2}\left(\mathrm{X}=\mathrm{Cl}^{-}, \mathrm{I}^{-}, \mathrm{NCS}^{-}, \mathrm{CN}^{-}\right)^{5}$ and 17 -electron rhenium(II) carbonyl phosphine complexes. ${ }^{6}$ These works are based on the combination of preparative electrochemistry, followed by ESI-MS analysis. However, preparative electrochemistry suffers from several disadvantages. First, considerable time is needed in order to achieve full conversion, thereby limiting the resolution of potential dependent investigations. Second, the long reduction times often involve fouling of the electrode surface by polymeric by-products. Third, the reduced compounds have ample time to participate in unwanted subsequent chemical reactions among themselves or with the oxidized forms. Fourth, preparative electrochemistry followed by ESI-MS studies involves considerable sample handling which may lead to oxygen penetration and impurity introduction.

The importance of flow-through electrochemical cells connected to a mass spectrometer and the instrumentation involved have been recently reviewed. ${ }^{7}$ Cole et al..${ }^{8,9}$ Bond et al.,$^{10}$ and Van Berkel et al., ${ }^{11,12}$ used different configurations of electrochemical cells coupled to on-line ESI mass spectrometers for the investigation of redox reactions. We devised an on-line concentric electrochemical cell connected to ESI-MS in which the counter electrode and its products are separated from the reacting stream reaching the ESI-MS in order to isolate and protect the reduced compounds from the oxidized substances generated at the counter electrode.

Oxygen-containing organomolybdenum complexes are especially intriguing since, in spite of their ability to attain a large number of oxidation states, relatively little is known about their speciation in protic solutions or about their electrochemistry. More information is available, on the other hand, on inorganic oxomolybdenum compounds, including ESI-MS speciation studies. Singly, doubly, and triply charged heteropoly and isopolymolybdate anions were studied in organic and aqueous organic solutions ${ }^{13,14}$ though the reduction products of these compounds were not investigated by mass spectrometry. The subject of the present study is the identification of the electrochemical reduction products of complex $\mathrm{Cp}_{2}{ }_{2} \mathrm{Mo}_{2} \mathrm{O}_{5}$ in an aqueous-methanol solution. $\mathrm{Cp}_{2}{ }_{2} \mathrm{Mo}_{2} \mathrm{O}_{5}$ is a member of a relatively broad family of high oxidation organometallic compounds, some of which have shown remarkable stoichiometric and/or catalytic chemical transformations. Although some of these molecules are stable in an aqueous environment and are even synthesized in water, their aqueous chemistry has rarely been investigated. For the particular case of $\mathrm{Cp}_{2}{ }_{2} \mathrm{Mo}_{2} \mathrm{O}_{5}$, while most studies have been carried out in organic solvents, ${ }^{15-19}$ other contributions have restricted the use of aqueous media to some aspects of the synthetic procedure. ${ }^{20-23}$ Some of us have recently reported an improved aqueous synthesis ${ }^{24}$ of $\mathrm{Cp}^{*}{ }_{2} \mathrm{Mo}_{2} \mathrm{O}_{5}$ and a detailed investigation of its speciation in a $\mathrm{MeOH}-\mathrm{H}_{2} \mathrm{O}$ mixture by conductivity studies. ${ }^{25}$ An additional interest in this molybdenum system is the redox-richness of the metal. Thus, 
exploring the redox behavior of $\mathrm{Cp}_{2}{ }_{2} \mathrm{Mo}_{2} \mathrm{O}_{5}$ as a prototype compound may open up avenues for the development of new stoichiometric or catalytic redox chemistry.

\section{Results and Discussion}

\section{(a) Studies of $\mathrm{Cp}_{2}{ }_{2} \mathrm{Mo}_{2} \mathrm{O}_{5}$ solutions and optimization of ESI-MS conditions}

The speciation of $\mathrm{Cp}_{2}{ }_{2} \mathrm{Mo}_{2} \mathrm{O}_{5}$ in water-methanol mixtures at various $\mathrm{pH}$ is known from recent kinetics and conductivity studies in one of our laboratories. ${ }^{25}$ The use of the mixed water-methanol medium was dictated by the insolubility of $\mathrm{Cp}_{2}{ }_{2} \mathrm{Mo}_{2} \mathrm{O}_{5}$ in pure water, while the hydrosoluble (but lipophobic) $\mathrm{Cp}^{*} \mathrm{MoO}_{3}{ }^{-}$ion is obtained under basic conditions. As a brief summary of the speciation studies, compound $\mathrm{Cp}^{*}{ }_{2} \mathrm{Mo}_{2} \mathrm{O}_{5}$ was found to exist as a molecular dinuclear species in organic solvents, but self-ionization to $\mathrm{Cp} * \mathrm{MoO}_{2}{ }^{+}$and $\mathrm{Cp}^{*} \mathrm{MoO}_{3}{ }^{-}$occurs to a larger and larger extent as the water content in the solvent mixture increases. In $20 \% \mathrm{MeOH}-\mathrm{H}_{2} \mathrm{O}$, the compound behaves as a strong electrolyte affording, as the preponderant species, $\mathrm{Cp}^{*} \mathrm{MoO}_{2}{ }^{+}$at $\mathrm{pH}<2$ and $\mathrm{Cp}^{*} \mathrm{MoO}_{3}{ }^{-}$at $\mathrm{pH}>5$. Both species, plus a minor quantity of $\mathrm{Cp} * \mathrm{MoO}_{2}(\mathrm{OH})$, are present at intermediate $\mathrm{pH}$ values. ${ }^{25}$

The first part of our investigation was devoted to ESI-MS studies of the reactant $\mathrm{Cp}_{2}{ }_{2} \mathrm{Mo}_{2} \mathrm{O}_{5}$ in order to find the analytical conditions that will most closely reflect its speciation in solution. It is worth noting, in this respect, that ESIMS provides a sensitivity advantage over the previous analyses, which may have missed some less dominant species. On the other hand, even though ESI-MS is amongst the least intrusive mass spectrometric techniques, ${ }^{26}$ the ionization process may nevertheless introduce fragmentation and rearrangement processes leading to the observation of peaks of species that are not present in the solution. Therefore, the experimental conditions must be carefully optimized in order to minimize these phenomena. It is also important to verify that no redox process takes place in the ESI chamber in the absence of an applied electrochemical potential. For practical reasons, the ESI-MS studies were conducted in a 1:1 $\mathrm{MeOH}-\mathrm{H}_{2} \mathrm{O}$ mixture containing a $0.1 \mathrm{M} \mathrm{CH}_{3} \mathrm{COONH}_{4}-\mathrm{CH}_{3} \mathrm{COOH}$ buffer at $\mathrm{pH} 4$. Under these conditions, a substantial amount of dimolybdenum species (either the neutral $\mathrm{Cp}^{*}{ }_{2} \mathrm{Mo}_{2} \mathrm{O}_{5}$ or the tight ion pair, $\mathrm{Cp}^{*} \mathrm{MoO}_{2}{ }^{+}, \mathrm{Cp}^{*} \mathrm{MoO}_{3}{ }^{-}$) is also present in solution.

Figure 1 compares the ESI-MS analysis of a $0.1 \mathrm{mM}$ solution of $\mathrm{Cp}_{2}{ }_{2} \mathrm{Mo}_{2} \mathrm{O}_{5}$ in positive $(a)$ and negative $(b)$ detection modes. The positive mode ESI-MS spectrum exhibits four major isotopic patterns, corresponding to mono-, di-, tri- and tetra- nuclear species, respectively. The mononuclear region shows two major species (see left insert in Figure 1(a)), both exhibiting the characteristic, 7-peak isotopic pattern of a single Mo atom. The first species is characterized by an isotopic pattern at $m / z=259-267$ and corresponds to the cation $\mathrm{Cp}^{*} \mathrm{MoO}_{2}{ }^{+}$, while the second one starting $18 \mathrm{~m} / z$ units higher $(\mathrm{m} / \mathrm{z}=277-285)$ is assigned to the protonated hydroxo species, $\mathrm{Cp}^{*} \mathrm{MoO}_{3} \mathrm{H}_{2}{ }^{+}$. While the former is a solution-borne species, the latter results from the protonation of $\mathrm{Cp}^{*} \mathrm{MoO}_{2}(\mathrm{OH})$ and $\mathrm{Cp}^{*} \mathrm{MoO}_{3}{ }^{-}$in the $\mathrm{ESI}$ chamber (its $\mathrm{pK}_{\mathrm{a}}$ was estimated as ca. -2). Because of this protonation process, the ESI-MS fails to duplicate the known acid-base speciation. $^{25}$

((Figure 1))

Two major species appear in the dimolybdenum region, both being characterized by the expected isotopic distributions for species containing two Mo centers (see second insert of Figure 1(a)). The most abundant isotopic pattern is at $m / z=535-551$ which corresponds to the protonated form of $\mathrm{Cp}^{*}{ }_{2} \mathrm{Mo}_{2} \mathrm{O}_{5}$. As stated above, this compound exists as a molecular species in organic solvents (including pure $\mathrm{MeOH}$ ) but it partially dissociates in the presence of water. In a $1: 1 \mathrm{MeOH}-\mathrm{H}_{2} \mathrm{O}$ mixture, as used in this study, the conductivity investigations showed that part of the 
dinuclear compound is undissociated. The observed peak can therefore be attributed to the combination of $\mathrm{Cp}_{2}{ }_{2} \mathrm{Mo}_{2} \mathrm{O}_{5}$ with protons originating from the ammonium buffer. The less abundant and lighter pattern $(\mathrm{m} / z$ 517-533) in this region has 18 fewer mass units than the previous one and is therefore assigned to a dehydrated form. Probably, one of the $\mathrm{Cp}^{*}$ protons is involved in the process leading to this species, thereby signaling ESI-MS fragmentation. ${ }^{27,28}$

The isotope patterns at $\mathrm{m} / \mathrm{z}, 793-815$ and $\mathrm{m} / \mathrm{z} 1090-1117$ fit very well the calculated distributions of $\mathrm{Cp}_{3}{ }_{3} \mathrm{Mo}_{3} \mathrm{O}_{7}{ }^{+}$(slope $=1.0005$, correlation coefficient, $\left.\mathrm{R}^{2}=0.999\right)$ and $\mathrm{Cp}^{*}{ }_{4} \mathrm{Mo}_{4} \mathrm{O}_{11} \mathrm{H}_{3}{ }^{+}$(slope $\left.=1.008, \mathrm{R}^{2}=0.9998\right)$, respectively. ${ }^{29}$ Thus, both complexes still feature the metal in the oxidation state +6 . It should be noted that a deviation of a single atomic mass unit (AMU), corresponding to a 1-electron reduction process, can be easily distinguished by the isotope distribution fit. For example, curve fitting of the isotope distribution of a hypothetical $\mathrm{Cp}^{*}{ }_{4} \mathrm{Mo}_{4} \mathrm{O}_{11} \mathrm{H}_{4}{ }^{+}$to the observed isotope pattern for the tetranuclear species gives a slope of 1.004 but a correlation coefficient, $\mathrm{R}^{2}=0.5451$. Of course, the fitting of lower molecular weight molybdenum complexes to the observed patterns is even more sensitive to the assigned composition.

The negative mode spectrum of the same $\mathrm{Cp}_{2}{ }_{2} \mathrm{Mo}_{2} \mathrm{O}_{5}$ solution is given in Figure $1(b)$. The major pattern at $m / z=$ 275-283 corresponds to the deprotonated mononuclear species, $\mathrm{Cp}^{*} \mathrm{MoO}_{3}^{-}$(left insert). The second major distinguishable pattern (right insert, $\mathrm{m} / z=415-431$ ) is assigned to a species of formula $\mathrm{Cp}^{*} \mathrm{Mo}_{2} \mathrm{O}_{6}{ }^{-}$, i.e. the product of the replacement of one $\mathrm{Cp}^{*-}$ group with $\mathrm{O}^{2-}$, a result of ESI-MS fragmentation. The negative mode spectrum also shows a much higher background current, relative to the positive mode spectrum, for $m / z$ greater than 500 . For these reasons, all further studies were conducted in the positive ion mode.

Two additional ESI-MS parameters were singled out for further optimization: The temperature of the heated capillary and the heated capillary voltage. Figure 2(a) shows the ESI-MS spectrum recorded under the same conditions of Figure 1(a), except that the heated capillary was held at $200^{\circ} \mathrm{C}$ rather than at $100^{\circ} \mathrm{C}$. The differences between the two spectra confirm that the heated capillary temperature is a decisive factor in ESI-MS studies of our compounds. A comparison between the inserts of Figure 1(a) and Figure 2(a), reveals that $\mathrm{CpMoO}_{3} \mathrm{H}_{2}{ }^{+}$almost completely disappears at high temperatures while the abundance of a new species with $m / z=273-281$ (corresponding to $\mathrm{CpMoO}_{3} \mathrm{H}_{2}{ }^{+}-3 \mathrm{H}$ ) evidently resulting from a fragmentation process - increases. Furthermore, the daughter product with $\mathrm{m} / z=517-533$ in the dinuclear region becomes the preponderant species, while the original isotope pattern of the protonated dinuclear species $\mathrm{Cp}_{2}{ }_{2} \mathrm{Mo}_{2} \mathrm{O}_{5} \mathrm{H}^{+}$almost completely disappears. In addition, other fragmentation products are also formed in relatively large proportions. Evidently, $\mathrm{Cp}_{2}{ }_{2} \mathrm{Mo}_{2} \mathrm{O}_{5}$ is cleaved at high temperatures.

((Figure 2))

The temperature dependence that was exemplified in Figure 2(a) is further elaborated upon in Figure 2(b). The figure shows the dependence of several of the most abundant positive ion peaks as a function of the heated capillary temperature. Peak heights were normalized to the highest peak observed at the given heated capillary temperature. Under increased temperature conditions the abundance of the parent peak of the protonated $\mathrm{Cp}_{2}{ }_{2} \mathrm{Mo}_{2} \mathrm{O}_{5}$ decreases, while the abundance of the secondary peak of the dehydrated moiety goes through a maximum at $120-180^{\circ} \mathrm{C}$ and then also decreases. The abundance of the monomeric form $\mathrm{Cp}^{*} \mathrm{MoO}_{2}{ }^{+}$increases monotonically with temperature indicating a somewhat surprising thermal stability for this ion, whereas its relative abundance at $100^{\circ} \mathrm{C}$ amounts to less than $10 \%$ of the dinuclear peak.

The relative abundances of the tri- and tetranuclear molybdenum species decrease steadily with the heated capillary temperature. This decrease suggests that the tri- and tetranuclear molybdenum species originate from the aqueous solution and that they were not generated by condensation reactions in the ESI chamber. Condensation 
reactions and dehydration should increase at higher temperatures contrary to the tendency that is exhibited in Figure $2(b)$. Thus, we believe that these compounds do exist in the solution although they were not observed before by any other technique. These results directed our subsequent experiments to minimal source temperatures, which was set at $100^{\circ} \mathrm{C}$ for detector sensitivity reasons.

The capillary voltage value was optimized (+25 V) during the automatic tuning process of our MS in order to give the highest sensitivity for the mass of $\mathrm{Cp}^{*}{ }_{2} \mathrm{Mo}_{2} \mathrm{O}_{5} \mathrm{H}^{+}$. Since prior studies pointed to the sensitivity of the observed spectra of organometallic complexes to the heated capillary voltage, ${ }^{30}$ we have carried out a set of tests in order to check the influence of this parameter in our case. The experiments showed that the spectra were not significantly changed so long as the heated capillary voltage remained within the -25 to $+100 \mathrm{~V}$ range, see Figure 2(c). It should be pointed out that no reduced molybdenum species were observed even when this potential was set as low as $-100 \mathrm{~V}$. Only for more negative cone voltages $(<-110 \mathrm{~V})$ did a reduction peak become observable $(\mathrm{m} / \mathrm{z}=777-799$, assigned to $\left.\mathrm{Cp}^{*}{ }_{3} \mathrm{Mo}_{3}{ }^{\mathrm{V}, \mathrm{V}, \mathrm{VI}} \mathrm{O}_{6}{ }^{+}\right)$.

The concentration dependence of the peak intensities for the five major species are shown in Figure 3 . The relative abundances of the $\mathrm{Cp} * \mathrm{MoO}_{3} \mathrm{H}_{2}{ }^{+}$and $\mathrm{Cp} * \mathrm{MoO}_{2}{ }^{+}$species are virtually concentration independent, whereas those of all other species, including the dinuclear $\mathrm{Cp}^{*}{ }_{2} \mathrm{Mo}_{2} \mathrm{O}_{5} \mathrm{H}^{+}$, increase with concentration. Given the established equilibrium between the dinuclear $\mathrm{Cp}_{2}{ }_{2} \mathrm{Mo}_{2} \mathrm{O}_{5}$, on one side, and the separate ions $\mathrm{Cp}^{*} \mathrm{MoO}_{2}{ }^{+}$and $\mathrm{Cp}^{*} \mathrm{MoO}_{3}{ }^{-}$, on the other side, in $\mathrm{MeOH}-\mathrm{H}_{2} \mathrm{O}$ solutions of various proportions, an increase of the relative abundance of dinuclear species with the concentration is expected. In principle, the observed increase in relative intensity with concentration for the trinuclear and tetranuclear peaks could be equally explained by invoking similar solution equilibria. Since we have shown that a water-rich environment favors the spontaneous ionization of $\mathrm{Cp}^{*}{ }_{2} \mathrm{Mo}_{2} \mathrm{O}_{5}$ into $\mathrm{Cp}^{*} \mathrm{MoO}_{2}{ }^{+}$and $\mathrm{Cp}^{*} \mathrm{MoO}_{3}{ }^{-}$, we propose that the trinuclear species derives from e.g. the combination of $\mathrm{Cp}^{*} \mathrm{MoO}_{3}{ }^{-}$with two $\mathrm{Cp}^{*} \mathrm{MoO}_{2}{ }^{+}$ions, as shown in Scheme 1.

\section{((Figure 3))}

$(($ Scheme 1))

For the tetranuclear species, a similar association process may occur, although a simple breakdown into mononuclear charged components and a tentative structure for the assembled species cannot be as easily imagined as for the trinuclear species. It should be further remarked that these ionic association processes should be favored by the low polarity of the 50:50 water-methanol mixture. In the more polar 80:20 mixture where our previous speciation study was conducted, ${ }^{25}$ no evidence for the presence of these ion was obtained, although the kinetics and conductivity may have been insensitive to the presence of small amounts of these species.

The choice of a buffer based on the ammonium cation, rather than on other metal cations, was dictated by the observation of complicating metal addition processes when the latter were used. For instance, Figure 4 shows the basic set of peaks of the dinuclear species in the presence of $1 \mathrm{M} \mathrm{LiBF}_{4}$ (acidified by acetic acid to $\mathrm{pH}$ 3.3). Competitive protonation and formation of adducts with metal cations, the latter being preponderant, take place and both adducts are discerned in the ESI-MS spectrum. The formation of metal ion adducts in preference to protonation in the ESI-MS chamber is a known phenomenon for neutral organometallic molecules. ${ }^{31,32}$

((Figure 4)) 
In addition to obtaining optimal ESI-MS parameters two important interim conclusions could be reached based on the open circuit studies of $\mathrm{Cp}^{*}{ }_{2} \mathrm{Mo}_{2} \mathrm{O}_{5}$ in methanol-water-acetate solutions. First, condensation reactions do not occur to a large extent in the ESI chamber; the tri- and tetranuclear molybdenum species appear to be already present in solution. Second, reduced molybdenum compounds are not generated to a noticeable extent in the ESI-MS. This condition is a prerequisite for our further on-line electrochemical reduction - ESI-MS studies.

\section{(b) On-line electrochemical reduction - ESI-MS study}

Figure 5(a) shows the background, $3 \mathrm{mV} / \mathrm{sec}$ voltammogram of a $\mathrm{MeOH} / \mathrm{H}_{2} \mathrm{O}$ (1:1) solution (acetic buffer, $\mathrm{pH} 4$ ) recorded in a regular three-compartment electrochemical cell with a glassy carbon working electrode. Curve $(b)$ shows the voltammogram of a $1 \mathrm{mM}$ solution of $\mathrm{Cp}_{2}{ }_{2} \mathrm{Mo}_{2} \mathrm{O}_{5}$. The reduction wave starts at approximately $-0.45 \mathrm{~V} v s$ saturated $\mathrm{Ag} / \mathrm{AgCl}$ electrode. The current - potential curves at the forward and backward scans nearly coincide and the height of the reduction wave is virtually independent of the scan rate for a rather wide range of scan rates $(3-100 \mathrm{mV} / \mathrm{s})$. The last two observations indicate that the electrochemical reduction of $\mathrm{Cp}_{2}{ }_{2} \mathrm{Mo}_{2} \mathrm{O}_{5}$ is controlled by an interfacial step and it is not diffusion limited. A slope change at $\mathrm{E}=-0.65 \mathrm{~V}$ implies that an additional reduction step is switched on at this potential. It is quite obvious that the identification of the electroreduction products is impossible solely on the basis of the voltammetric experiment.

$(($ Figure 5))

Preparative electrolysis studies at $-0.6,-0.7$ and $-0.8 \mathrm{~V}$ using a conventional $10 \mathrm{~mm}$ diameter glassy carbon electrode showed a gradual decrease of the current after prolonged polarization ( 2 hours) due to the formation of a thick oxide film on the electrode surface. This was accompanied by the accumulation of polymeric products in the solution, which increased the turbidity of the solution and could also be detected by ESI-MS studies. Thus, we preferred to direct the electrochemical studies to the flow-through configuration because the shorter time scale of the experiment and the constant renewal of the electrolyzed solution insured the absence of contamination from slower secondary reactions.

The electrochemical investigations were therefore pursued in a combined on-line electrochemical cell - ESI-MS experimental set up (Figure 6). The flow configuration and the characteristics of this setup are described in full details elsewhere. ${ }^{33}$ Briefly, in this cell the feed stream reaches the sample electrode through the outer annulus of a concentric dual capillary arrangement. The feed stream split into an outer stream that diverge outward and washes away the cell solution and an axial stream that flows inward through a 20 micrometer gap between the glassy carbon sample and the flat end of the dual capillary arrangement. The feed converges into an inner capillary transfer line that leads to the mass spectrometer. We preferred this type of setup over a regular tabular flow cell in order to avoid chemical interferences due to the oxidation reactions on the counter electrode. This configuration also minimizes ohmic potential drops in the cell. Note that, unlike regular flow-through electrochemical detectors that operate under mass transport limited conditions, we target a kinetically controlled reaction. Thus, using conventional flow-through cells, oxidized compounds that are generated at the counter electrode will most likely escape electroreduction on the working electrode and will reach the transfer line to the mass spectrometer. This phenomenon may result either in the appearance of oxidized species in the MS or, even worse, in the occurrence of chemical reactions between the compounds generated at the counter and working electrodes. The flow cell of Figure 6 assures the confinement of the compounds being generated at the counter electrode away from the transfer line to the mass spectrometer. 
((Figure 6))

During the coupled EC-ESI-MS experiments, mass spectra are continuously recorded and thus a threedimensional domain of signal intensities as a function of $\mathrm{m} / \mathrm{z}$ and time is generated. Projections of this space onto a $m / z$ axis for a given time range gives a time-integrated traditional mass spectrum, while the projection onto the time axis for a given $\mathrm{m} / \mathrm{z}$ range gives the time evolution of the chosen species. Under potential ramp constraint a potential dependent generation or consumption of the specific compounds is obtained.

In order to translate the time dependent relative abundances into potential dependent curves it is necessary to measure the lag time in the transfer line from the electrochemical flow cell to the mass spectrometer and to estimate the degree of back-mixing (i.e. signal averaging) in the transfer line. These parameters were determined by the application of a potential step between $-0.35 \mathrm{~V}$ and $-0.9 \mathrm{~V}$ to the $\mathrm{GC}$ working electrode. According to the voltammetric curve $(b)$ shown in Figure 5, the Mo species in the solution are exclusively in their oxidized state at $E=-0.35 \mathrm{~V}$, while at $E=-$ 0.9 reduction process occurs. Figure 7 shows that the application of the potential step sharply decreases the concentration of $\mathrm{Cp}_{2}{ }_{2} \mathrm{Mo}_{2} \mathrm{O}_{5} \mathrm{H}^{+}$. The intensity of the signal starts to decrease after a delay time of $\sim 25$ seconds. This seemingly corresponds to the retention time in the transfer line, in agreement with flow calculations. An additional 15 seconds interval is required to reach the half height of the concentration step change. The deviation of the MS response from a sharp step change is attributed to backmixing in the transfer line and to the time constant of the ESI interface. Thus, the "lag time" of the instrument is approximately 40 seconds. Therefore, the coupled EC-ESI-MS experiment with a continuous potential linear scan were recorded under quite slow scan rate conditions, i.e. $0.5 \mathrm{mV} \mathrm{s}^{-1}$.

$(($ Figure 7))

Figure 8 shows the potential dependent abundance of all major species that are present in solution under open circuit conditions, i.e. the mononuclear $\mathrm{Cp}^{*} \mathrm{MoO}_{2}{ }^{+}$and $\mathrm{Cp}^{*} \mathrm{MoO}_{3} \mathrm{H}_{2}{ }^{+}$, the dinuclear $\mathrm{Cp}_{2} \mathrm{Mo}_{2} \mathrm{O}_{5} \mathrm{H}^{+}$, the trinuclear $\mathrm{Cp}_{3}{ }_{3} \mathrm{Mo}_{3} \mathrm{O}_{7}{ }^{+}$and the tetranuclear $\mathrm{Cp}^{*}{ }_{4} \mathrm{Mo}_{4} \mathrm{O}_{9}(\mathrm{OH})_{3}{ }^{+}$(see Figure $1(a)$ ), during the electroreduction process. The recorded signal was obtained by summing the relative abundances of all the peaks in each respective $m / z$ range covering the entire isotope envelope. The time axis of the product evolution curve was synchronized with the corresponding potential scale using $40 \mathrm{~s}$ delay time based on the potential step-change studies. During the backward, anodic scan, the concentration profiles essentially follow the same pattern observed in the cathodic scan, indicating that the experiment is not significantly polluted by film deposition processes. It is to be noted that all species start to be reduced at approximately the same potential. This would seem consistent with the presence of rapid equilibria between the various complexes, as proposed above, and with the selective reduction of only one of these species. However, it cannot be excluded that all the different species, or at least some of them, are reduced independently at approximately the same potential. A clarification of this point needs additional experiments under different concentration and $\mathrm{pH}$ conditions, which are in progress and will be reported in due course.

((Figure 8)) 
The mass spectrum measured at the switching potential, see Figure 9, reveals a set of new peaks corresponding to the different products of electrochemical reduction. New isotopic patterns corresponding to the formation of reduced mononuclear, dinuclear, trinuclear and tetranuclear species evolved at reduced potentials.

((Figure 9))

The potential dependence of the MS intensities of the reduced molybdenum species are shown in Figure 10, together with their corresponding MS isotopic patterns and assigned structures. The latter are based on the fit of the observed MS isotope patterns to the calculated isotope distributions. It should be noted that, although the molecular weight and Mo nuclearity are unambiguous, the assigned structures are only tentative. Alternative possibilities exist; for instance, species $\mathrm{Cp}_{2}{ }_{2} \mathrm{Mo}_{2} \mathrm{O}_{2}(\mathrm{OAc})_{2}{ }^{+}$may display two terminal oxo and two bridging acetato ligands, or two bridging oxo and two terminal (chelating) acetato ligands, or all ligands may be bridging as shown in Figure 10. The chosen assignments are based on the comparison with related examples from the literature. The closest analogues to the dinuclear complexes are half-sandwich sulfido and alkylsulfido species, extensively investigated in the groups of Rakowski-Dubois and Pétillon. ${ }^{34-36}$ No previous report of compounds where the $\mathrm{Cp}^{*}{ }_{2} \mathrm{Mo}_{2}{ }^{\mathrm{n}+}$ core is fully coordinated by hard, oxygen-based ligands seems to be available, the exception being made for the starting material $\mathrm{Cp}_{2}{ }_{2} \mathrm{Mo}_{2} \mathrm{O}_{5}$ and the corresponding $\mathrm{Mo}^{\mathrm{V}}$ dimer, $\mathrm{Cp}_{2}{ }_{2} \mathrm{Mo}_{2} \mathrm{O}_{4} \cdot{ }^{24,37,38}$ Related trinuclear $\mathrm{Cp} *$ Mo species having formula $\left[\mathrm{Cp}^{*}{ }_{3} \mathrm{Mo}_{3} \mathrm{O}_{6} \mathrm{H}_{\mathrm{n}}\right]^{2+}$ $(\mathrm{n}=4,5,6)$, on the other hand, have been previously reported by Bottomley et al. ${ }^{39}$ Amongst tetranuclear oxo clusters, the closest relationship is found with a $\mathrm{Cp}$ derivative, a red isomer of " $\mathrm{CpMoO}_{2}$ ", whose nuclearity was based solely on molecular weight determinations. ${ }^{40}$ The more stable organge isomer has a dinuclear structure. A more reduced tetranuclear oxo cluster, $\mathrm{Cp}_{4}{ }_{4} \mathrm{Mo}_{4} \mathrm{O}_{7}$, formally a $\mathrm{Mo}^{4.5+}$ species, has also been previously described. ${ }^{41}$ No indication is obtained, however, that the latter species is obtained under our experimental conditions.

((Figure 10))

As shown in Figure 10 (central column), the isotopic envelopes of most identified species do not overlap with the other nearby isotopic patterns. An exception is the dinuclear complex $\mathrm{Cp}_{2}{ }_{2} \mathrm{Mo}_{2} \mathrm{O}_{4} \mathrm{H}^{+}(\mathrm{m} / z$ 519-535), which overlaps with another species having $m / z=517-533$, a daughter ion obviously deriving from hydrogen loss from the Cp* rings. The voltage dependent intensity of the $\mathrm{Cp}^{*}{ }_{2} \mathrm{Mo}_{2} \mathrm{O}_{4} \mathrm{H}^{+}$species is obtained by integrating a $\mathrm{m} / z$ region where the overlap with the minor species is minimal (i.e. $m / z=532-534)$. Complex $\mathrm{Cp}^{*} \mathrm{MoO}(\mathrm{OAc})^{+}(\mathrm{m} / z=302-310)$ overlaps with another species having one fewer mass unit, indicating fragmentation with loss of hydrogen atoms. The envelope of the reduced trinuclear species is shifted exactly by 16 units to lower $m / z$ from that of its precursor complex $\mathrm{Cp}_{3}{ }_{3} \mathrm{Mo}_{3} \mathrm{O}_{7}{ }^{+}$, suggesting its formulation as a proton-free hexaoxo species.

The assignment of the chemical formulas for the reduced species is further supported by ion trap $\mathrm{MS}^{\mathrm{n}}$ fragmentation studies, all results being collected in Table 1. All $\mathrm{MS}^{\mathrm{n}}$ studies were conducted with isolation width corresponding to the whole range of the observed isotope patterns. The $m / z=302-310$ monoacetate complex shows loss of acetic acid and formation of a methanol adduct in the $\mathrm{MS}^{2}$. Similarly, the diacetate mononuclear complex $(\mathrm{m} / z 345$ 353) exhibits loss of an acetic acid unit. The low stability of these low-weight mononuclear fragments did not allow further $\mathrm{MS}^{3}$ fragmentation studies. The assignment of the $m / z=519-535$ to a $\mathrm{Cp}_{2}{ }_{2} \mathrm{Mo}_{2} \mathrm{O}_{4} \mathrm{H}^{+}$is supported by $\mathrm{MS}^{2-}$ $\mathrm{MS}^{4}$ subsequent fragmentations showing a consecutive series of single dehydrations. In addition, a MS ${ }^{\mathrm{n}}$ study of 
separately synthesized $\mathrm{Cp}_{2}{ }_{2} \mathrm{Mo}_{2} \mathrm{O}_{4}$ revealed an identical fragmentation pathway. The assignment of $\mathrm{m} / \mathrm{z}=561-577$ to a $\mathrm{Cp}_{2}{ }_{2} \mathrm{Mo}_{2} \mathrm{O}_{3}(\mathrm{OAc})$ species is supported by $\mathrm{MS}^{2}$ fragmentation showing neutral losses of an acetyl fragment or water. The isotope pattern at $m / z=604-620$ is assigned to $\mathrm{Cp}_{2}{ }_{2} \mathrm{Mo}_{2} \mathrm{O}_{2}(\mathrm{OAc})_{2}{ }^{+}$on the basis of the acetyl loss and dimer cleavage to give the $\mathrm{Cp}^{*} \mathrm{MoO}_{2}(\mathrm{OAc})^{+}$and $\mathrm{Cp}^{*} \mathrm{MoO}(\mathrm{OAc})_{2}{ }^{+}$cationic fragments in the $\mathrm{MS}^{2}$. The $\mathrm{Cp}_{2}{ }_{2} \mathrm{Mo}_{2} \mathrm{O}(\mathrm{OAc})_{3}{ }^{+}$complex $(m / z=$ 647-663) gives rise to three different fragmentations at different collision energies, corresponding to loss of a one and two acetyl groups, and to dimer cleavage to give the mononuclear fragment $\mathrm{Cp}^{*} \mathrm{Mo}(\mathrm{OAc})_{2}{ }^{+}$. Further $\mathrm{MS}^{3}$ fragmentation of $\mathrm{Cp}^{*} \mathrm{Mo}(\mathrm{OAc})_{2}{ }^{+}$reveals an additional acetyl loss. Finally, $\mathrm{MS}^{4}$ fragmentation of $\mathrm{Cp}^{*} \mathrm{Mo}(\mathrm{OAc})^{+}$reveals one oxygen atom loss.

((Table 1))

The $\mathrm{MS}^{\mathrm{n}}$ fragmentation of the trinuclear species is even more complicated. The primary species $\mathrm{Cp}^{*}{ }_{3} \mathrm{Mo}_{3} \mathrm{O}_{6}{ }^{+}$ $(m / z=777-799)$ produces four fragments in the $\mathrm{MS}^{2}$. The first two correspond to loss of $\mathrm{C}_{5} \mathrm{Me}_{4} \mathrm{CH}_{2}$ and $\mathrm{C}_{5} \mathrm{Me}_{4} \mathrm{CH}_{2}+$ $\mathrm{H}_{2} \mathrm{O}$, respectively, the third is a methanol adduct of the second and the fourth corresponds to $\mathrm{Cp}_{2} \mathrm{Mo}_{2} \mathrm{O}_{4}{ }^{+}$which results from the loss of $\mathrm{Cp}^{*} \mathrm{MoO}_{2}$. It should be noted that the latter cleavage involves disruption of two oxo bridges and indeed it occurs at much higher collision energy compared to the first three processes. $\mathrm{MS}^{3}$ fragmentation of the methanol adduct results in $\mathrm{MeOH}$ loss and a subsequent $\mathrm{MS}^{4}$ fragmentation reveals four ions corresponding to $\mathrm{Cp}^{*}$ loss plus formation of three solvent adducts of the resulting fragment. $\mathrm{MS}^{3}$ and $\mathrm{MS}^{4}$ fragmentation of $\mathrm{Cp}_{2}{ }_{2} \mathrm{Mo}_{2} \mathrm{O}_{4}{ }^{+}$gives rise to subsequent dehydration processes. An $\mathrm{MS}^{\mathrm{n}}$ study of the reduced tetranuclear species could not be carried out because of the very low abundance of these peaks.

Table 2 presents the approximate potential values for the appearance of the various reduced species that may be measured on Figure 10. The analysis of these values enables us to derive a certain number of conclusions: $(i)$ within a given nuclearity, the potential becomes more negative as the oxidation state decreases, as one would expect; (ii) when comparing species having the same formal oxidation state, the dinuclear compounds are always obtained at a less negative potential than the mononuclear ones, while the tetranuclear $\mathrm{Cp}^{*}{ }_{4} \mathrm{Mo}_{4} \mathrm{O}_{8} \mathrm{H}^{+}$species is obtained at approximately the same potential $\left(-0.52 \mathrm{~V}\right.$ ) as the dinuclear $\mathrm{Cp}_{2}{ }_{2} \mathrm{Mo}_{2} \mathrm{O}_{4} \mathrm{H}^{+}$species $-0.48 \mathrm{~V}$ ); (iii) the latter complex is obtained at a less negative reduction potential than the other $\mathrm{Mo}^{\mathrm{V}}$ dinuclear species containing an acetate ligand; (iv) finally, this potential nearly matches the potential at which the peaks of the starting complex start to disappear (Figure 8). The large deviation between the threshold formation potentials and the mid-intensity potential, $E_{1 / 2}$, points to kinetically controlled formation reactions for all of the reduced molybdenum species. This is unfortunate since it precludes the direct evaluation of the corresponding thermodynamic formation parameters for these new compounds.

((Table 2))

These combined observations may be interpreted as follows. The mononuclear products are likely to derive from the one-electron reduction of $\mathrm{Cp}^{*} \mathrm{MoO}_{2}{ }^{+}$, affording a neutral radical. At more negative potentials, the latter species may be further reduced, possibly after a protonation stage. At each oxidation state level, two competing processes may occur, namely acetate/hydroxide exchange, and dimerization (accompanied by the establishment of a metal-metal bond). For instance, the neutral $\mathrm{Mo}^{\mathrm{V}}$ intermediate may dimerize to $\mathrm{Cp}^{*}{ }_{2} \mathrm{Mo}_{2} \mathrm{O}_{4}$, which is then detected by the ESI-MS in its protonated form, or it may be protonated and the resulting $\mathrm{Cp}^{*} \mathrm{MoO}(\mathrm{OH})^{+}$species may undergo a hydroxide- 
acetate exchange leading to the observed $\mathrm{Cp} * \mathrm{MoO}(\mathrm{OAc})^{+}$. The driving force of the rapid and irreversible metal-metal bond formation would account for the less reducing potential which is needed to generate an oligonuclear species relative to a mononuclear one at the same oxidation state level. It is also possible, however, that the higher nuclearity products are obtained by direct reduction of the higher nuclearity species that are present in solution. It can be noted that each one-electron reduction for the mononuclear and dinuclear species is formally accompanied by the replacement of one oxygen atom with an acetato group (corresponding to a mass increase of 43 units). The only exception to this substitution rule is the observation of two different compounds having the $\mathrm{Mo}_{2}{ }^{\mathrm{V}, \mathrm{V}}$ core and related to each other by the formal replacement of an $\mathrm{OH}$ with an acetato group. The spectrum in Figure 9 does not show any mononuclear species with a mass greater that the 345-353 envelope, nor dinuclear species with a mass greater that the 647.0-664.0 envelope. This suggests that no Mo species in oxidation states lower than +4 are produced under the chosen experimental conditions.

The major trinuclear product obtained under reducing conditions is a $\mathrm{Mo}_{3}{ }^{\mathrm{V}, \mathrm{V}, \mathrm{VI}}$ species. On the other hand, the same basic structure was reported for the dicationic $\mathrm{Mo}_{3}{ }^{\mathrm{IV}, \mathrm{IV}, \mathrm{V}}, \mathrm{Mo}_{3}{ }^{\mathrm{IV}, \mathrm{IV}, \mathrm{IV}}$, and $\mathrm{Mo}_{3}{ }^{\mathrm{III}, \mathrm{IV}, \mathrm{IV}}$ complexes $\mathrm{Cp}_{3}{ }_{3} \mathrm{Mo}_{3} \mathrm{O}_{6} \mathrm{H}_{\mathrm{n}}{ }^{2+}(\mathrm{n}$ $=4,5,6) .{ }^{39}$ Although the isotope envelope simulation indicate quite clearly the nature of the major product, minor amounts of products of further reduction cannot be excluded. We did not observe any signals attributable to dicationic species. It is possible that the reduction potential range and the conditions used in the present study do not allow access to the more reduced known trinuclear species, which were in fact previously obtained by zinc reduction of $\mathrm{Cp}^{*} \mathrm{MoO}{ }_{2} \mathrm{Cl}$ under non aqueous conditions. ${ }^{39}$

Concerning the tetranuclear reduction products, the $\left[\mathrm{Cp}_{4}{ }_{4} \mathrm{Mo}_{4} \mathrm{O}_{8} \mathrm{H}\right]^{+}$species may be related to the kinetic isomer previously identified for the $\mathrm{Cp}$ system when complex $\mathrm{CpMoCl}_{4}$ is hydrolyzed, namely $\mathrm{Cp}_{4} \mathrm{Mo}_{4} \mathrm{O}_{8}{ }^{40}$ It is believed that this complex does not contain metal-metal bonds, whereas the dinuclear $\mathrm{Cp}_{2} \mathrm{Mo}_{2} \mathrm{O}_{4}$ isomer does. ${ }^{42}$ Therefore, the formation of this tetranuclear compound from precursors that are themselves devoid of metal-metal interactions is to be expected. The mixed-valence $\left[\mathrm{Cp}^{*}{ }_{4} \mathrm{Mo}_{4} \mathrm{O}_{10} \mathrm{H}_{2}\right]^{+}$species does not have any equivalent in the literature. The shape of the abundance vs. potential curve indicates that a direct reduction to other species, possibly the tetranuclear $\mathrm{Mo}(\mathrm{V})$ cluster, becomes more favorable at more negative potentials.

As clearly shown by the cone voltage optimization study (Figure 2(c)), the experimental conditions of the positive mode electrospray process cannot induce, by themselves, an oxidation state decrease for the analyte. Therefore, the reduced molybdenum products shown in Figure 10 must originate from the electrochemical reactions in the electrochemical cell. The simple chemical composition of these species and the fact that they contain unfragmented acetate and pentamethylcyclopentadienyl ligands lead us to believe that they are all indeed solution borne species.

\section{Conclusion}

The coupled EC-ESI-MS technique has proven to be a powerful analytical tool for the investigation of complex electrochemical transformations. From the electroreducion of $\mathrm{Cp}_{2}{ }_{2} \mathrm{Mo}_{2} \mathrm{O}_{5}$, at least six previously unreported species have been identified and the potential required for the generation of each one of them has been assessed. These species may be described as oxo and/or acetate-stabilized $\mathrm{Cp} * \mathrm{Mo}^{\mathrm{n}+}, \mathrm{Cp}_{2}{ }_{2} \mathrm{Mo}_{2}{ }^{\mathrm{n}+} \mathrm{Cp}^{*} \mathrm{Mo}_{3}{ }^{\mathrm{n}+}$ and $\mathrm{Cp}^{*}{ }_{4} \mathrm{Mo}_{4}{ }^{\mathrm{n}+}$ complexes. These species, as well as analogues with less coordinating anionic ligands, are expected to lead to new aqueous coordination chemistry, catalysis and electrocatalysis. Indeed, a few dinuclear and trinuclear species that are related to those 
observed by this EC-ESI-MS investigation have been synthesized and isolated in one of our laboratories. These investigations are described in separate publications..$^{43,44}$

\section{Experimental Section}

General Remarks: The starting compound was prepared according to the literature procedure. ${ }^{24}$ Unless otherwise stated, all solutions were prepared in $\mathrm{H}_{2} \mathrm{O} / \mathrm{MeOH}(1: 1)$ containing $\mathrm{CH}_{3} \mathrm{COONH}_{4}(0.25 \mathrm{M})$ and buffered to $\mathrm{pH} 4.0$ by the addition of $\mathrm{CH}_{3} \mathrm{COOH}$. A lower concentration of $\mathrm{MeOH}$ in the spray solution resulted in significant losses of relative abundances. All reagents were purchased from Aldrich. Methanol was purchased from Baker and was of HPLC grade. The water was triple distilled.

Electrospray Mass Spectrometry: Finnigan (San Jose, USA) LCQ quadrupole ion trap mass spectrometer equipped with an electrospray ionization (ESI) interface was used for data acquisition. ESI was operated either in positive or in negative ion mode. In negative mode the tip of the capillary and the sampling cone were maintained at potentials of $-3.5 \mathrm{kV}$ (spray voltage) and $-70 \mathrm{~V}$ (capillary voltage) respectively. In positive mode the spray voltage was at $3.6 \mathrm{kV}$ and capillary voltage was $25 \mathrm{~V}$. The source temperature was the subject of a separate study. Mass spectra were acquired by scanning the mass analyzer from m/z 100 to 2000 with 5 total microscans. Maximum injection time into ion trap was $50 \mathrm{~ms}$. Sample injection flow rate was $5 \mathrm{uL}^{*} \mathrm{~min}^{-1}$. In all experiments, helium was introduced at an estimated pressure of $1 \mathrm{~m}$ Torr to improve the ion trapping efficiency. During $\mathrm{MS}^{\mathrm{n}}$ experiments the compounds were isolated in the ion trap with isolation width of isotope pattern and activated by using increased collision energy.

Electrochemical Investigations: PARC 273 potentiostat/galvanostat (Princeton, USA) was used. Three compartment electrochemical cell with a disk glassy carbon working electrode (Metrohm, Herisau, Switzerland), platinum counter electrode and $\mathrm{Ag} / \mathrm{AgCl}$ (sat) reference electrode (Metrohm) was used for the voltammetric studies.

\section{Coupled Electrochemistry - Electrospray Mass Spectrometry: Figure 6 shows a scheme of the} experimental set up used in the present study. Detailed description of the electrochemical set-up is given elsewhere. ${ }^{33}$ The set up is comprised of a three-compartment electrochemical cell placed in a pressure chamber, a two coaxial capillary set, a micropositioning device, and a mass spectrometer equipped with an electrospray ionization (ESI) interface. The working glassy carbon electrode (1) was pressed to the bottom opening of a three compartments electrochemical cell (3). A Pt wire counter electrode and $\mathrm{Ag} / \mathrm{AgCl}$ ( $\mathrm{KCl}$ sat.) reference electrodes were placed in the side compartments of the cell. All reported potentials are given relative to this reference electrode. The electrolyte in the cell was $0.25 \mathrm{M} \mathrm{CH}_{3} \mathrm{COONH}_{4}$ in $\mathrm{H}_{2} \mathrm{O} / \mathrm{MeOH}$ (1:1) buffered to $\mathrm{pH} 4.0$ by $\mathrm{CH}_{3} \mathrm{COOH}$. $1 \mathrm{mM} \mathrm{Cp}{ }_{2}{ }_{2} \mathrm{Mo}_{2} \mathrm{O}_{5}$ solution in the same electrolyte was pumped through the annulus of the capillary set to the electrode. A coaxial capillary set $(4,5)$ was used to deliver the reagent solution to the electrode and to transfer the product stream to the interface of the mass spectrometer through the inner capillary. A syringe pump was used to deliver the feed stream to a T-junction (7) located outside the pressure chamber (6), from which the stream was directed through the annulus between the two capillaries to the electrode. The product stream $\left(F_{0}\right)$ was pumped, following the interaction with the electrode, upward through the inner capillary (4) by the excess pressure in the pressure vessel. All capillaries were fused silica from SGE (Austin, USA). The inner capillary was $25 \mu \mathrm{m}$ inner diameter, $285 \mu \mathrm{m}$ outer diameter, $15 \mathrm{~cm}$ long. The product stream was 
diluted with excess methanol delivered from a glass beaker (8). The liquid flow rates and dilution ratio (product stream/methanol) were controlled by setting the pressure in the pressure vessel and choice of capillary length and inner diameter . The cell pressure was $2600 \mathrm{kPa}$. After mixing with the auxiliary liquid, the sample stream was delivered to the ESI interface of the mass spectrometer by a $30 \mathrm{~cm}$ long, $50 \mu \mathrm{m}$ inner diameter capillary. The flow rate of the product stream was $c a 0.7 \mu \mathrm{min}^{-1}$. The methanol flow in the auxiliary capillary was $14 \mu 1 \mathrm{~min}^{-1}$. The reagent flowrate $\left(F_{1}\right)$ was set to $4 \mu \mathrm{min}^{-1}$.

\section{Acknowledgments}

RP and MV thank the CNRS and the Ministery of Research for funding. DS thanks the Conseil Régional de Bourgogne for a post-doctoral fellowship. ADM and OL acknowledge the financial support of the Israel Science Foundation. JG thanks the U. Bourgogne for a visiting professorship. We are grateful to the French Embassy in Israel for an Arc-enCiel/Keshet travel grant and to Prof. G. Tsirlina for useful discussions.

\section{References}

M. Yamashita and J. B. Fenn, J. Phys. Chem., 1984, 88, 4451-4459.

R. E. March and R. J. Hujhes, 'Quadrupole Storage Mass Spectrometry in Chemical analysis', ed. J. D. Wiefordner, J. Wiley and Sons, 1989.

M. L. Vestal, Mass Sperctrom. Rev., 1983, 2, 447-480.

W. Henderson, B. K. Nicholson, and L. J. McCaffrey, Polyhedron, 1998, 17, 4291-????.

G. Wolfbauer, A. M. Bond, and D. R. MacFarlane, J. Chem. Soc., Dalton Trans., 1999, 4363-4372.

A. M. Bond, R. Colton, D. G. Humphrey, P. J. Mahon, G. A. Snook, V. Tedesco, and J. N. Walter, Organometallics, 1998, 17, 2977-2985.

B. Bittins-Cattaneo, E. Cattaneo, P. Konigshoven, and W. Vielstich, in "Electroanalytical Chemistry", Vol. 16, ed. A. J. Bard, Marcel-Dekker: NY-Basel-Hong Kong, 1991

X. Xu, W. Lu, and R. B. Cole, Anal. Chem., 1996, 68, 4244-4253.

W. Lu, X. Xu, and R. B. Cole, Anal. Chem., 1997, 69, 2478-2484.

A. M. Bond, R. Colton, A. D'Agostino, A. J. Downard, and J. C. Traeger, Anal. Chem., 1995, 67, 1691-1695.

F. Zhou and G. J. Van Berkel, Anal. Chem., 1995, 67, 3643-3649.

H. Deng and G. J. Van Berkel, Anal. Chem., 1999, 71, 4284-4293.

D. K. Walanda, R. C. Burns, G. A. Lawrance, and E. I. von Nagy-Felsobuki, J. Chem. Soc., Dalton Trans., 1999, 311-321.

B. Salignac, S. Riedel, A. Dolbecq, F. Secheresse, and E. Cadot, J. Am. Chem. Soc., 2000, 122, 10381-10389.

M. Herberhold, W. Kremnitz, A. Razavi, H. Schöllhorn, and U. Thewalt, Angew. Chem. Int. Ed. Engl., 1985,

24, 601-602.

K. Isobe, S. Kimura, and Y. Nakamura, J. Organometal. Chem., 1987, 331, 221-228.

P. Gomez-Sal, E. de Jesus, P. Royo, A. Vazquez de Miguel, S. Martinez-Carrera, and S. Garcia-Blanco, J.

Organometal. Chem., 1988, 353, 191-196.

P. Leoni, M. Pasquali, L. Salsini, C. di Bugno, D. Braga, and P. Sabatino, J. Chem. Soc. Dalton Trans., 1989, 155-159.

A. L. Rheingold and J. R. Harper, J. Organometal. Chem., 1991, 403, 335-344.

J. W. Faller and Y. Ma, J. Organometal. Chem., 1988, 340, 59-69.

K. Umakoshi and K. Isobe, J. Organometal. Chem., 1990, 395, 47-53.

J. Sundermeyer, U. Radius, and C. Burschka, Chem. Ber., 1992, 125, 2379-2384.

M. S. Rau, C. M. Kretz, G. L. Geoffroy, and A. L. Rheingold, Organometallics, 1993, 12, 3447-3460.

D. Saurenz, F. Demirhan, P. Richard, R. Poli, and H. Sitzmann, Eur. J. Inorg. Chem., 2002, 1415-1424.

E. Collange, J. Garcia, and R. Poli, New J. Chem., 2002, 26, 1249-1256.

J. C. Traeger, Int. J. Mass Spectr., 2000, 200, 387-401.

R. Colton and J. C. Traeger, Inorg. Chim. Acta, 1992, 201, 153-155.

A. M. Bond, R. Colton, J. B. Cooper, J. C. Traeger, J. N. Walter, and D. M. Way, Organometallics, 1994, 13, 3434-3441.

M. J. Winter, '"Sheffield Chemputer"', http://www.shef.ac.uk/chemistry/chemputer/.

W. Henderson, J. S. McIndoe, B. K. Nicholson, and P. J. Dyson, Chem. Commun., 1996, 1183-????.

W. Z. Shou and R. F. Browner, Anal. Chem., 1999, 71, 3365-3373. 
E. C. Kempen and J. S. Brodbelt, Anal. Chem., 1999, 71, 5493-5500.

A. D. Modestov, S. Srebnik, O. Lev, and J. Gun, Anal. Chem., 2001, 73, 4229-4240.

M. Rakowski DuBois, Chem. Rev., 1989, 89, 1-9.

M. Rakowski DuBois, Polyhedron, 1997, 16, 3089-3098.

F. Y. Pétillon, P. Schollhammer, J. Talarmin, and K. W. Muir, Coord. Chem. Rev., 1998, 178-179, $203-247$.

H. Arzoumanian, A. Baldy, M. Pierrot, and M. Petrignani, J. Organometal. Chem., 1985, 294, 327-331.

E. de Jesus, A. Vazquez de Miguel, P. Royo, A. M. M. Lanfredi, and A. Tiripicchio, J. Chem. Soc., Dalton Trans., 1990, 2779-2784.

F. Bottomley, J. Chen, K. F. Preston, and R. C. Thompson, J. Am. Chem. Soc., 1994, 116, 7989-7995.

M. Cousins and M. L. H. Green, J. Chem. Soc., 1964, 1567-1572.

F. Bottomley, V. Sanchez, R. C. Thompson, O. O. Womiloju, and Z. Q. Xu, Can. J. Chem., 2000, 78, $383-394$.

C. Couldwell and K. Prout, Acta Crystallogr., 1978, B34, 933-934.

F. Demirhan, J. Gun, O. Lev, A. Modestov, R. Poli, and P. Richard, J. Chem. Soc, Dalton Trans., 2002, 21092111.

F. Demirhan, P. Richard, and R. Poli, Inorg. Chim. Acta, in press. 
Table 1. Assigned formulas and $\mathrm{MS}^{\mathrm{n}}$ studies of the reduction products formed during EC - ESI-MS studies of $\mathrm{Cp}_{2}{ }_{2} \mathrm{Mo}_{2} \mathrm{O}_{5}$.

\begin{tabular}{|c|c|c|c|c|c|c|}
\hline \multirow[t]{2}{*}{ Product of EC reduction } & \multicolumn{2}{|c|}{$\mathrm{MS}^{2}$} & \multicolumn{2}{|c|}{$\mathrm{MS}^{3}$} & \multicolumn{2}{|l|}{$\mathrm{MS}^{4}$} \\
\hline & loss & $\begin{array}{c}\text { Range of isotopic } \\
\text { pattern }\end{array}$ & loss & $\begin{array}{c}\text { Range of } \\
\text { isotopic pattern }\end{array}$ & loss & $\begin{array}{c}\text { Range of } \\
\text { isotopic pattern }\end{array}$ \\
\hline \multirow{6}{*}{$\begin{array}{l}\mathrm{Cp}^{*}{ }_{3} \mathrm{Mo}_{3}{ }^{\mathrm{V}, \mathrm{V}, \mathrm{VI}} \mathrm{O}_{6}{ }^{+} \\
m / z=777-799\end{array}$} & $-\mathrm{C}_{5} \mathrm{Me}_{4} \mathrm{CH}_{2}$ & $643-665$ & n. a. & n.a. & n.a & n.a \\
\hline & $-\mathrm{Cp}{ }^{*}-\mathrm{OH}$ & $625-647$ & n. a & n. a & n. a & n. a \\
\hline & $-\mathrm{Cp} *-\mathrm{OH}+\mathrm{MeOH}$ & $653-675$ & $-\mathrm{MeOH}$ & $625-647$ & $-\mathrm{H}_{2} \mathrm{O}$ & $607-629$ \\
\hline & & & & & $-\mathrm{C}_{5} \mathrm{Me}_{4} \mathrm{CH}_{2}+2 \mathrm{H}_{2} \mathrm{O}$ & $509-531$ \\
\hline & & & & & $-\mathrm{C}_{5} \mathrm{Me}_{4} \mathrm{CH}_{2}+2 \mathrm{H}_{2} \mathrm{O}+\mathrm{MeOH}$ & $541-563$ \\
\hline & & & & & $-\mathrm{C}_{5} \mathrm{Me}_{4} \mathrm{CH}_{2}+\mathrm{H}_{2} \mathrm{O}$ & $490-512$ \\
\hline \multirow{3}{*}{$\begin{array}{l}\mathrm{Cp}^{*}{ }_{2} \mathrm{Mo}_{2}{ }^{\mathrm{IV}, \mathrm{IV}} \mathrm{O}(\mathrm{OAc})_{3}{ }^{+} \\
m / z=647-663\end{array}$} & -OAc-O & $572-588$ & n.a & n.a & n.a & n.a \\
\hline & $-2(\mathrm{OAc})-\mathrm{O}$ & $513-529$ & n.a & n.a & n.a & n.a \\
\hline & $-\mathrm{Cp} * \mathrm{MoO}(\mathrm{OAc})$ & $345-353$ & $-\mathrm{OAc}$ & $286-294$ & $-\mathrm{O}$ & $270-278$ \\
\hline \multirow{4}{*}{$\begin{array}{l}\mathrm{Cp}^{*}{ }_{2} \mathrm{Mo}_{2}{ }^{\mathrm{IV},{ }^{V}} \mathrm{O}_{2}(\mathrm{OAc})_{2}{ }^{+} \\
m / z=604-620\end{array}$} & $-\mathrm{OAc}$ & $542-558$ & n.a & n.a & n.a & n.a \\
\hline & $-\mathrm{Cp} * \mathrm{MoO}(\mathrm{OAc})$ & $302-310$ & n.a & n.a & n.a & n.a \\
\hline & $-\mathrm{Cp} * \mathrm{MoO}$ & $361-369$ & n.a & n.a & n.a & $\mathrm{n} . \mathrm{a}$ \\
\hline & $-2(\mathrm{OAc})$ & $486-502$ & $-\mathrm{H}_{2} \mathrm{O}$ & $468-484$ & n.a & n.a \\
\hline \multirow{2}{*}{$\begin{array}{l}\mathrm{Cp}^{*}{ }_{2} \mathrm{Mo}_{2}{ }^{\mathrm{V}, \mathrm{V}} \mathrm{O}_{3}(\mathrm{OAc})^{+} \\
m / z=561-577\end{array}$} & $-\mathrm{OAc}$ & $502-518$ & n.a & n.a & n.a & n.a \\
\hline & $-\mathrm{H}_{2} \mathrm{O}$ & $543-559$ & n.a & n.a & n.a & n.a \\
\hline \multirow{2}{*}{$\begin{array}{l}\mathrm{Cp}^{*}{ }_{2} \mathrm{Mo}_{2}{ }^{\mathrm{V}, \mathrm{V}} \mathrm{O}_{4} \mathrm{H}^{+} \\
m / z=519-533\end{array}$} & Unclear & $360-368$ & n.a & n.a & n.a & n.a \\
\hline & $-\mathrm{H}_{2} \mathrm{O}$ & $501-517$ & $-\mathrm{H}_{2} \mathrm{O}$ & 483-499 & $-\mathrm{H}_{2} \mathrm{O}$ & $465-481$ \\
\hline $\begin{array}{l}\mathrm{Cp}^{*} \mathrm{Mo}^{\mathrm{IV}}(\mathrm{OAc})_{2}{ }^{+} \\
m / z=345-353\end{array}$ & $-\mathrm{AcOH}$ & $285-293$ & n.a & n.a & n.a & n.a \\
\hline $\begin{array}{l}\mathrm{Cp}^{*} \mathrm{Mo}^{\mathrm{V}} \mathrm{O}(\mathrm{OAc})^{+} \\
m / z=302-310\end{array}$ & $-\mathrm{AcOH}+\mathrm{MeOH}$ & $274-282$ & n.a & n.a & n.a & n.a \\
\hline
\end{tabular}

n.a. - not available 
Table 2. Threshold potential $\left(\mathrm{E}_{\mathrm{in}}\right)$ and half-wave potential $\left(\mathrm{E}_{1 / 2}\right)$ corresponding to the formation of reduced compounds during the EC-ESI-MS study of $\mathrm{Cp}^{*}{ }_{2} \mathrm{Mo}_{2} \mathrm{O}_{5}$ in Methanol-Water-Acetate solutions. ${ }^{\text {a }}$ Experimental conditions are described in the captions of Figure 9.

\begin{tabular}{llll}
\hline Compound & $m / z$ & $\mathrm{E}_{\text {in }}, \mathrm{V}$ & $\mathrm{E}_{1 / 2}, \mathrm{~V}$ \\
\hline $\mathrm{Cp}_{4}{ }_{4} \mathrm{Mo}_{4}{ }^{\mathrm{V}, \mathrm{VI}, \mathrm{VI}, \mathrm{VI}} \mathrm{O}_{10} \mathrm{H}^{+}$ & $1073-1100$ & -0.40 & -0.47 \\
$\mathrm{Cp}^{*}{ }_{4} \mathrm{Mo}_{4}{ }^{\mathrm{V}, \mathrm{V}, \mathrm{V}, \mathrm{V}} \mathrm{O}_{8} \mathrm{H}^{+}$ & $1040-1067$ & -0.52 & -0.61 \\
$\mathrm{Cp}^{*}{ }_{3} \mathrm{Mo}_{3}{ }^{\mathrm{V}, \mathrm{V}, \mathrm{VI}} \mathrm{O}_{6}{ }^{+}$ & $777-800$ & -0.48 & -0.75 \\
$\mathrm{Cp}^{*}{ }_{2} \mathrm{Mo}_{2}{ }^{\mathrm{IV}, \mathrm{V} V} \mathrm{O}(\mathrm{OAc})_{3}{ }^{+}$ & $647-663$ & -0.78 & -0.94 \\
$\mathrm{Cp}_{2}{ }_{2} \mathrm{Mo}_{2}{ }^{\mathrm{IV}, \mathrm{V}} \mathrm{O}_{2}(\mathrm{OAc})_{2}{ }^{+}$ & $604-620$ & -0.74 & -0.91 \\
$\mathrm{Cp}^{*}{ }_{2} \mathrm{Mo}_{2}{ }^{\mathrm{V}, \mathrm{V}} \mathrm{O}_{3}(\mathrm{OAc})^{+}$ & $561-577$ & -0.55 & -0.81 \\
$\mathrm{Cp}_{2}{ }_{2} \mathrm{Mo}_{2}{ }^{\mathrm{V}, \mathrm{V}} \mathrm{O}_{4} \mathrm{H}^{+}$ & $519-533$ & -0.48 & -0.77 \\
$\mathrm{Cp}^{*} \mathrm{Mo}^{\mathrm{IV}}(\mathrm{OAc})_{2}{ }^{+}$ & $345-353$ & -0.81 & -0.94 \\
$\mathrm{Cp}^{*} \mathrm{Mo}^{\mathrm{V}} \mathrm{O}(\mathrm{OAc})^{+}$ & $302-310$ & -0.76 & -0.92 \\
\hline
\end{tabular}

${ }^{\mathrm{a}} \mathrm{E}_{\text {in }}$ is defined as the potential corresponding to a $100 \%$ abundance increase over the background signal. $\mathrm{E}_{1 / 2}=$ potential at which half of the maximal signal intensity is obtained. 


\section{Captions for Figures}

Figure 1. Electrospray mass spectra of $0.1 \mathrm{mM}$ solution of $\mathrm{Cp}_{2}{ }_{2} \mathrm{Mo}_{2} \mathrm{O}_{5}$ in $\mathrm{H}_{2} \mathrm{O} / \mathrm{MeOH}(1: 1)$ at $\mathrm{pH}$. Heated capillary temperature $=100^{\circ} \mathrm{C}$. (a) Positive mode. (b) Negative mode. The largest $\mathrm{m} / \mathrm{z}$ peaks are marked in the figure and the first isotope in each isotopic pattern is marked in the inserts.

Figure 2. (a) Positive mode electrospray mass spectra of $0.1 \mathrm{mM}$ solution of $\mathrm{Cp}^{*}{ }_{2} \mathrm{Mo}_{2} \mathrm{O}_{5}$ in $\mathrm{H}_{2} \mathrm{O} / \mathrm{MeOH}(1: 1)$ at $\mathrm{pH} 4$. Heated capillary temperature $=200^{\circ} \mathrm{C}$. (b) and (c) Evolution of the relative intensity of selected species ( $\mathrm{Cp}^{*} \mathrm{MoO}_{2}^{+} ; \square: \mathrm{Cp}^{*} \mathrm{MoO}_{3} \mathrm{H}_{2}{ }^{+} ; \boldsymbol{\Delta}: \mathrm{Cp}^{*}{ }_{2} \mathrm{Mo}_{2} \mathrm{O}_{5} \mathrm{H}^{+}-\mathrm{H}_{2} \mathrm{O} ; \triangle: \mathrm{Cp}_{2}{ }_{2} \mathrm{Mo}_{2} \mathrm{O}_{5} \mathrm{H}^{+} ; \square: \mathrm{Cp}_{3}{ }_{3} \mathrm{Mo}_{3} \mathrm{O}_{7}{ }^{+}$species; $\diamond:$ $\mathrm{Cp}^{*}{ }_{4} \mathrm{Mo}_{4} \mathrm{O}_{11} \mathrm{H}_{3}{ }^{+}$) as a function of the heated capillary temperature (b) and heated capillary voltage (c)

Figure 3. Concentration dependence of the relative intensities of selected species. Spectra were recorded under conditions of Figure 1(a). $\diamond: \mathrm{Cp}^{*} \mathrm{MoO}_{2}^{+} ; \square: \mathrm{Cp}^{*} \mathrm{MoO}_{3} \mathrm{H}_{2}{ }^{+} ; \triangle: \mathrm{Cp}^{*}{ }_{2} \mathrm{Mo}_{2} \mathrm{O}_{5} \mathrm{H}^{+} ; \square: \mathrm{Cp}^{*}{ }_{3} \mathrm{Mo}_{3} \mathrm{O}_{7}{ }^{+} ; \diamond:$ $\mathrm{Cp}^{*}{ }_{4} \mathrm{Mo}_{4} \mathrm{O}_{11} \mathrm{H}_{3}{ }^{+}$.

Figure 4. Detailed positive mode electrospray mass spectra for a $0.1 \mathrm{mM}$ solution of $\mathrm{Cp}_{2}{ }_{2} \mathrm{Mo}_{2} \mathrm{O}_{5}$ in $\mathrm{H}_{2} \mathrm{O} / \mathrm{MeOH}(1: 1)$ in the presence $1 \mathrm{M} \mathrm{LiBF}_{4}(\mathrm{pH} 3.3)$.

Figure 5. Voltammetry in $0.25 \mathrm{M} \mathrm{NH}_{4} \mathrm{Ac}$ in $\mathrm{H}_{2} \mathrm{O} / \mathrm{MeOH}(1: 1)$ at $\mathrm{pH} 4$ on a GC electrode. Scan rate: $3 \mathrm{mV} / \mathrm{s}$. (a) blank solution; (b) $1 \mathrm{mM} \mathrm{Cp} *{ }_{2} \mathrm{Mo}_{2} \mathrm{O}_{5}$.

Figure 6. Scheme of the electrochemical cell used in this study. 1 - working electrode; 2 - transfer line to the ESI/MS; 3 - three compartments electrochemical glass cell; 4 - outer capillary; 5 - inner capillary 6 - pressure chamber; 7 - T-junction ; 8 - auxilliary fluid beaker; 9 - auxiliary capillary; 10 - pressure regulator; 11-Ztranslation stage; 12 - pressure chamber cover; 13 - rubber seal, 14 - steel rod Insert: A scheme of the miniature flow cell formed at the bottom of the coaxial capillary set up. $F_{1}$ is the feed through the annulus of the coaxial capillary set up ; $F_{0}$ is the product stream to the MS.

Figure 7. Response of the EC-ESI-MS(positive mode) to a potential step change of the GC electrode. Feed stream: $\mathrm{Cp}_{2}{ }_{2} \mathrm{Mo}_{2} \mathrm{O}_{5}(1 \mathrm{mM})$ in $0.25 \mathrm{M} \mathrm{NH}_{4} \mathrm{Ac} \mathrm{H}_{2} \mathrm{O} / \mathrm{MeOH}(1: 1)$ at $\mathrm{pH}$ 4. (a) potential step function. (b) time trace of the $\mathrm{Cp}_{2}{ }_{2} \mathrm{Mo}_{2} \mathrm{O}_{5} \mathrm{H}^{+}$signal intensity, integrated in the given $\mathrm{m} / \mathrm{z}$ range.

Figure 8. Mass spectra and potential dependent abundance of the initially present species during a linear potential sweep (scan rate $0.5 \mathrm{mV} \mathrm{s}^{-1}$ from $-0.35 \mathrm{~V}$ to $-1.0 \mathrm{~V}$ and back). Experimental conditions are as specified in Figure 7.

Figure 9. Mass spectrum recorded at $\mathrm{E}=-1.0 \mathrm{~V}$ (switching potential) during the EC-ESI-MS study of $\mathrm{Cp}_{2}{ }_{2} \mathrm{Mo}_{2} \mathrm{O}_{5}$. Experimental conditions are as specified in Figure 7.

Figure 10. Potential dependence of the relative abundance of selected species generated during the coupled electrochemistry - ESI-MS of $\mathrm{Cp}^{*}{ }_{2} \mathrm{Mo}_{2} \mathrm{O}_{5}$. Left: potential dependent evolution of the integrated signal. The $\mathrm{m} / \mathrm{z}$ range used for signal integration is specified above each curve. Center: expanded isotopic pattern. Right: 
proposed chemical structure. Experimental conditions are as specified in Figure 7. 
Figure 1
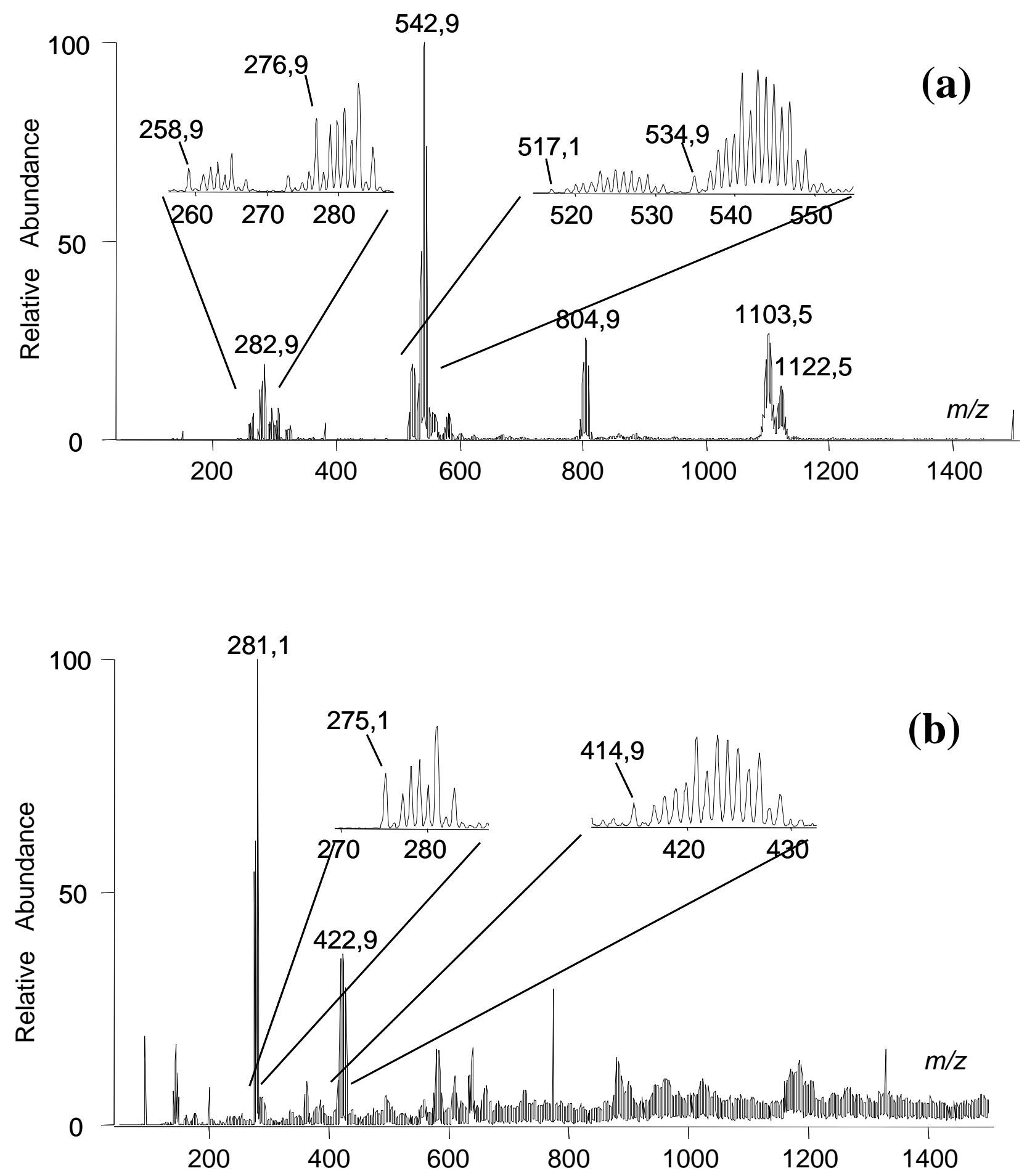
Figure 2
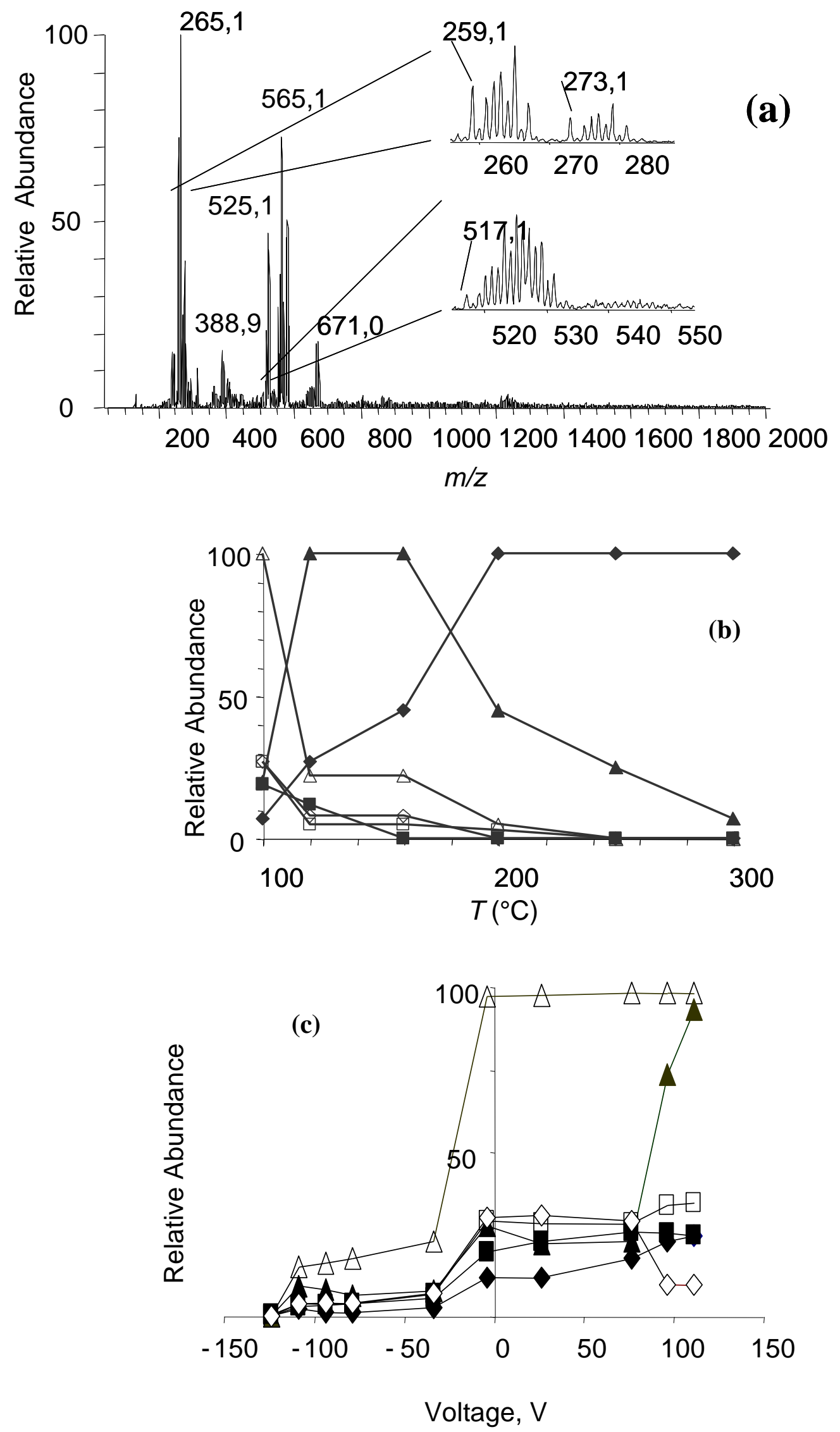
Figure 3

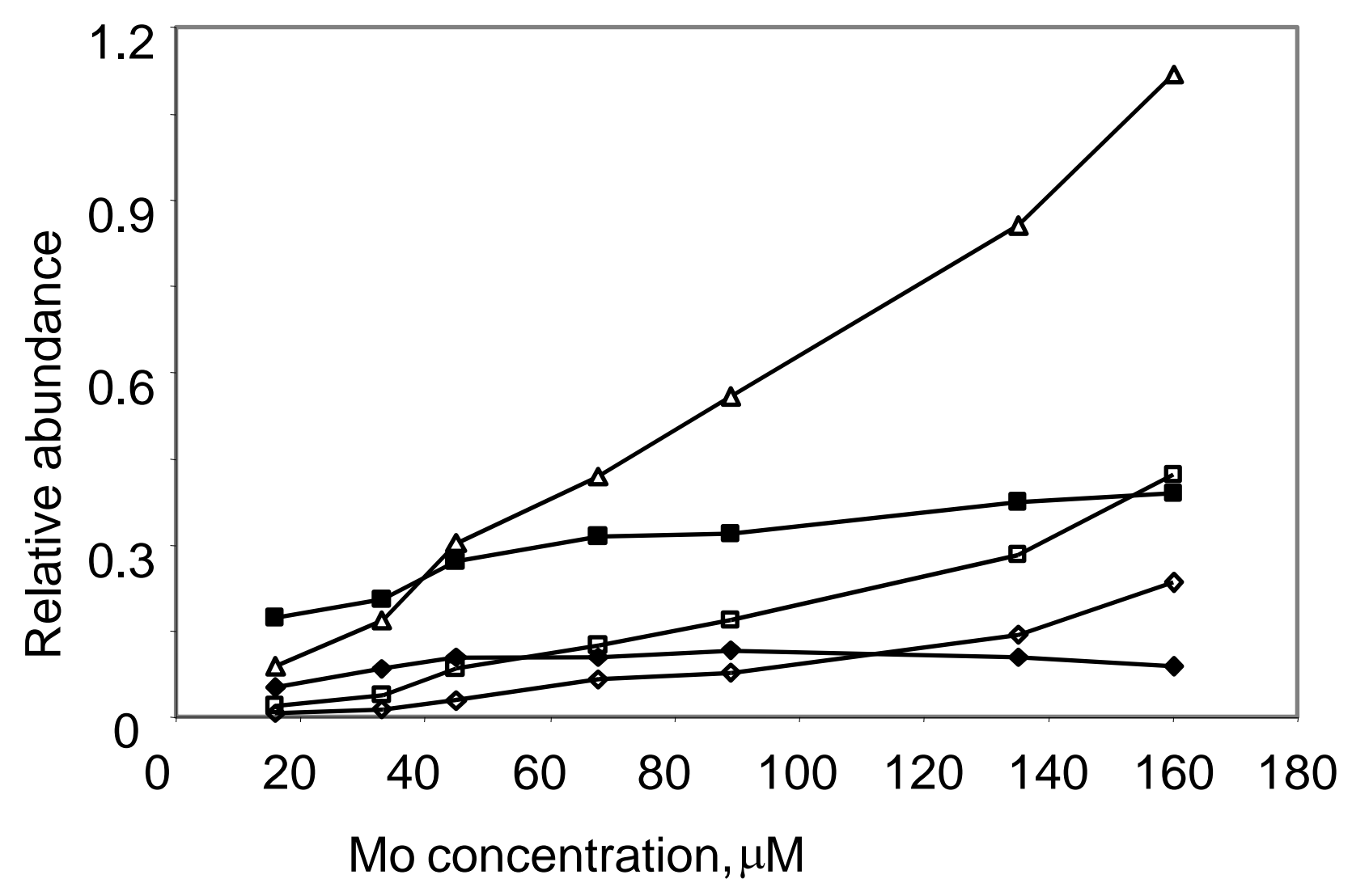


Figure 4

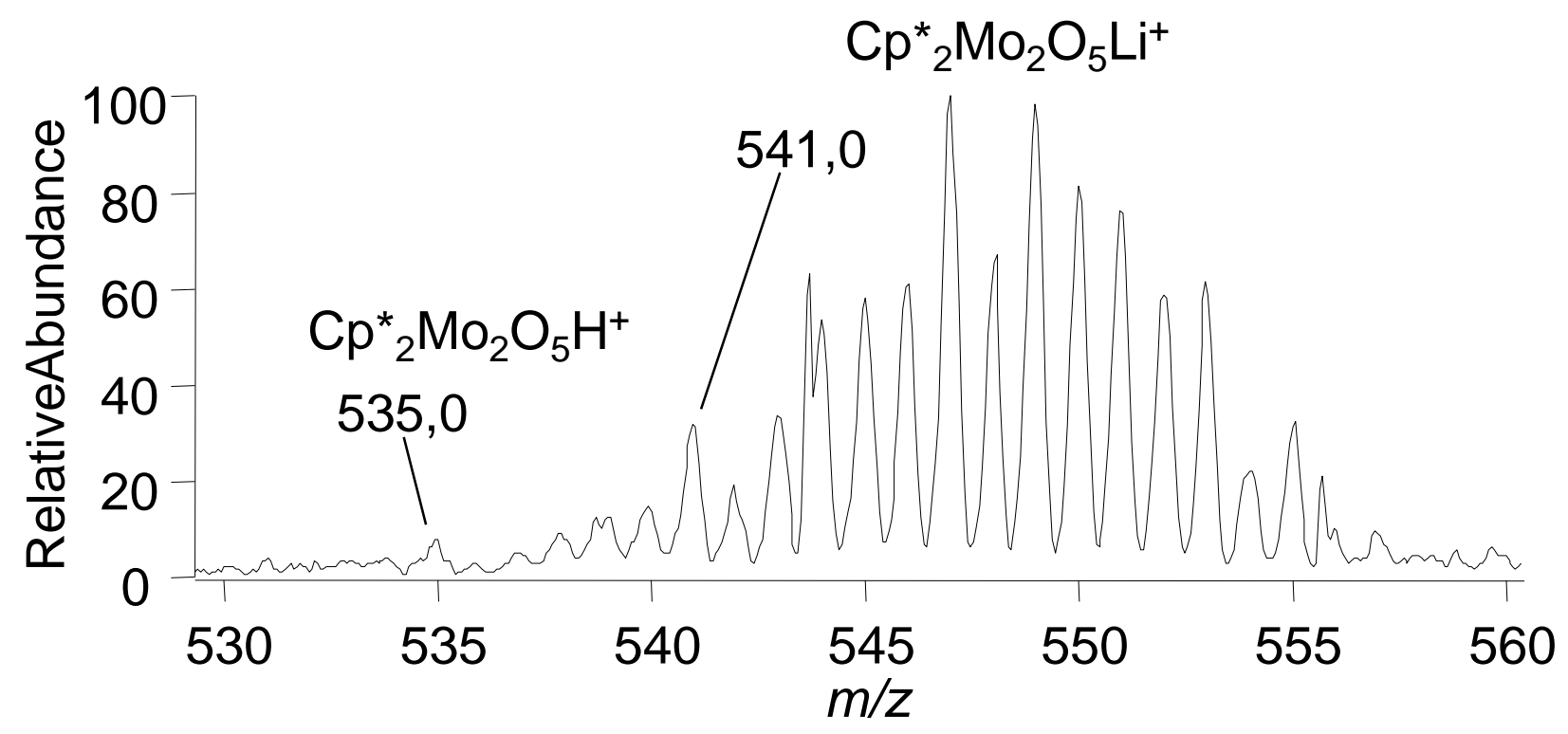


Figure 5

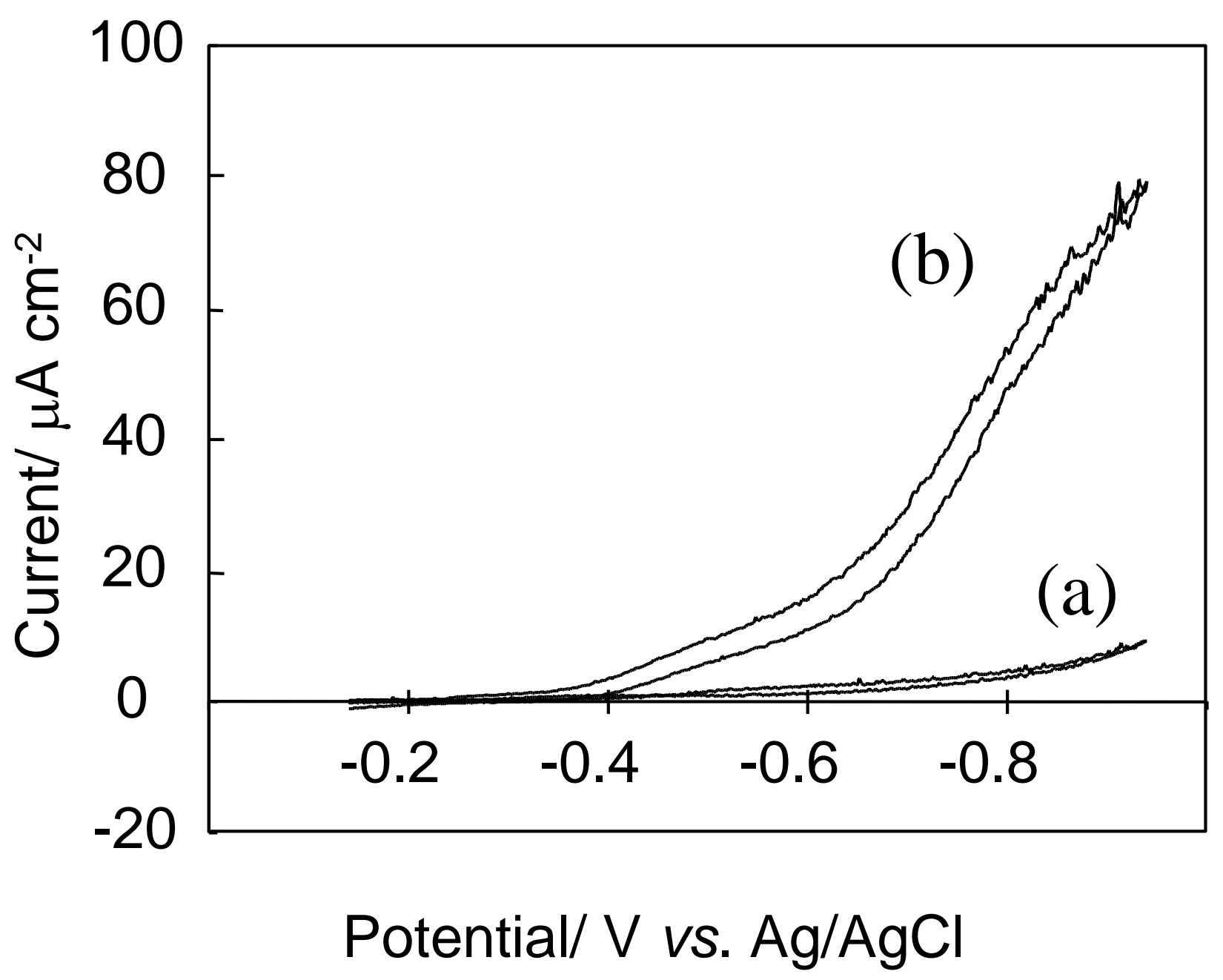


Figure 6

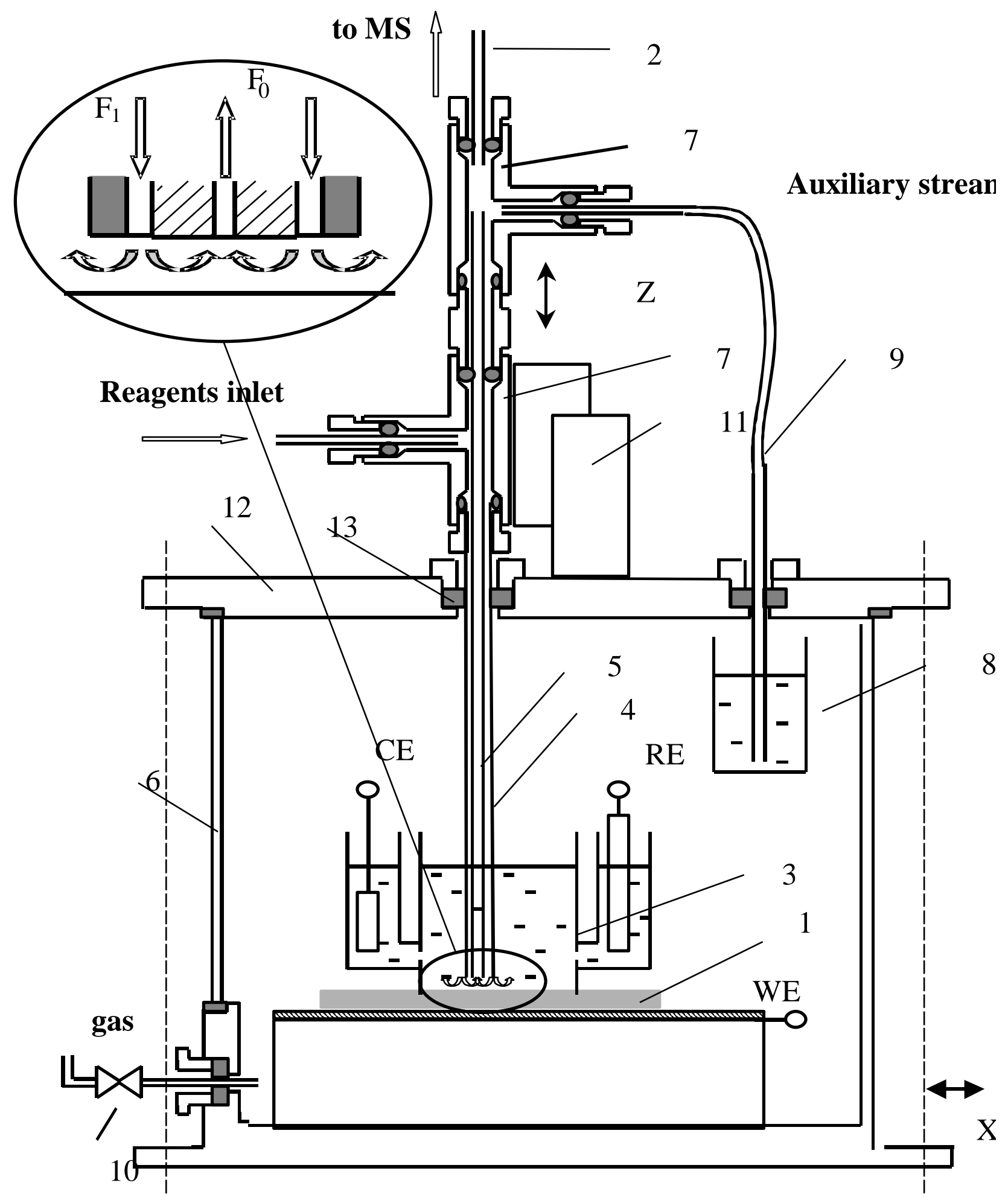


Figure 7
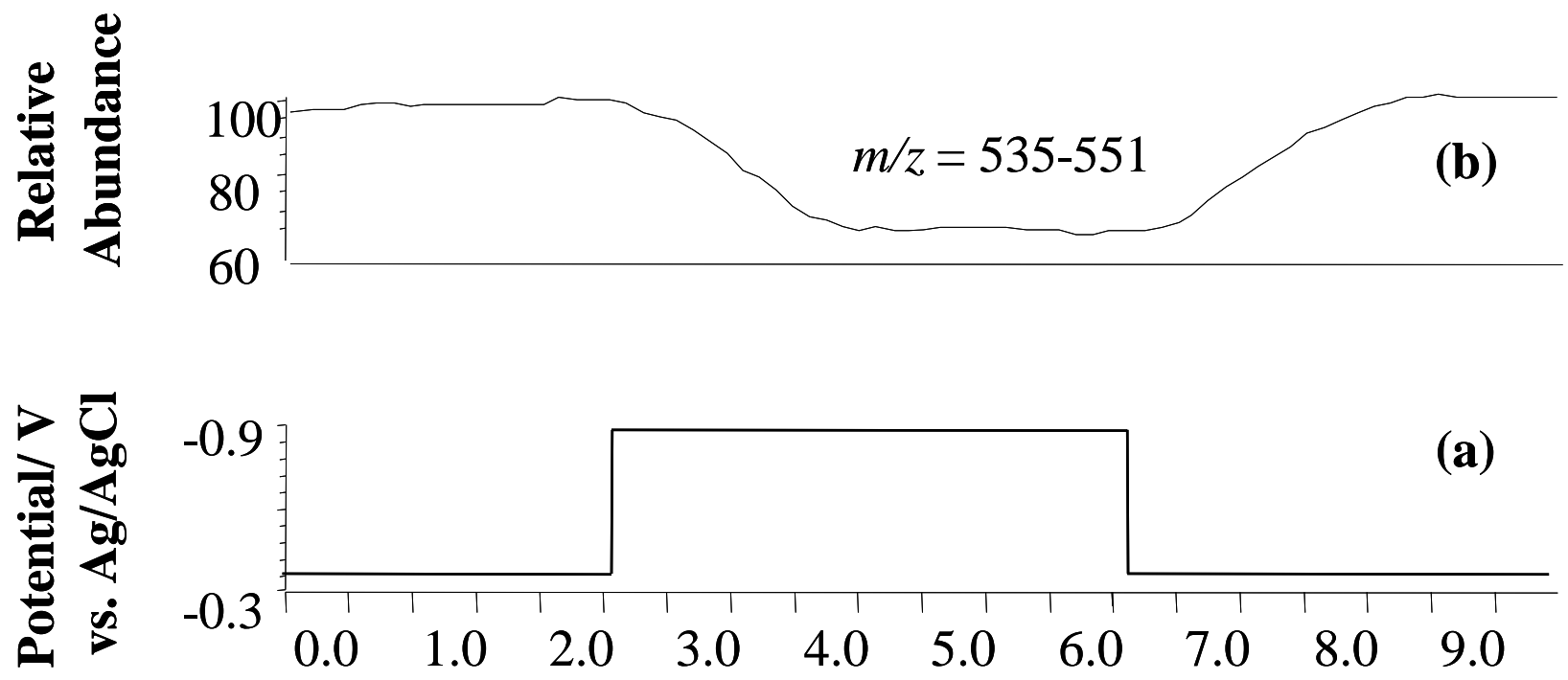

Time (min) 
Figure 8

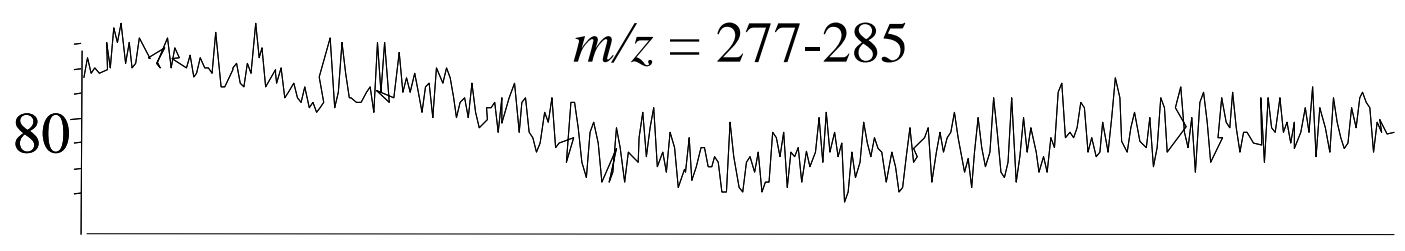

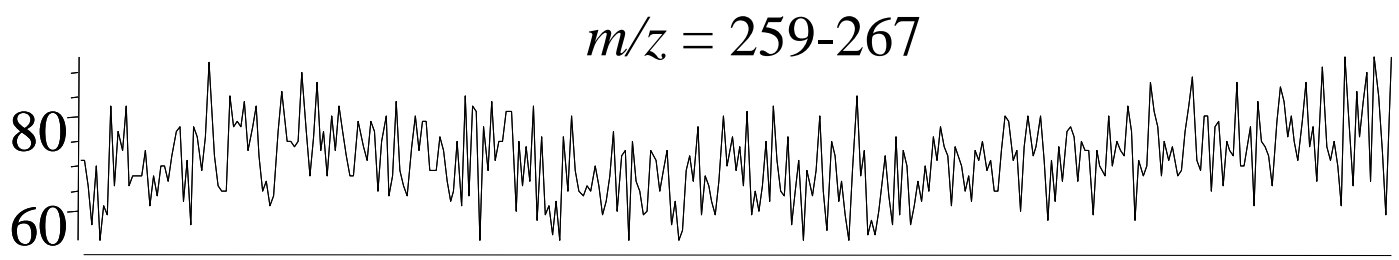

这
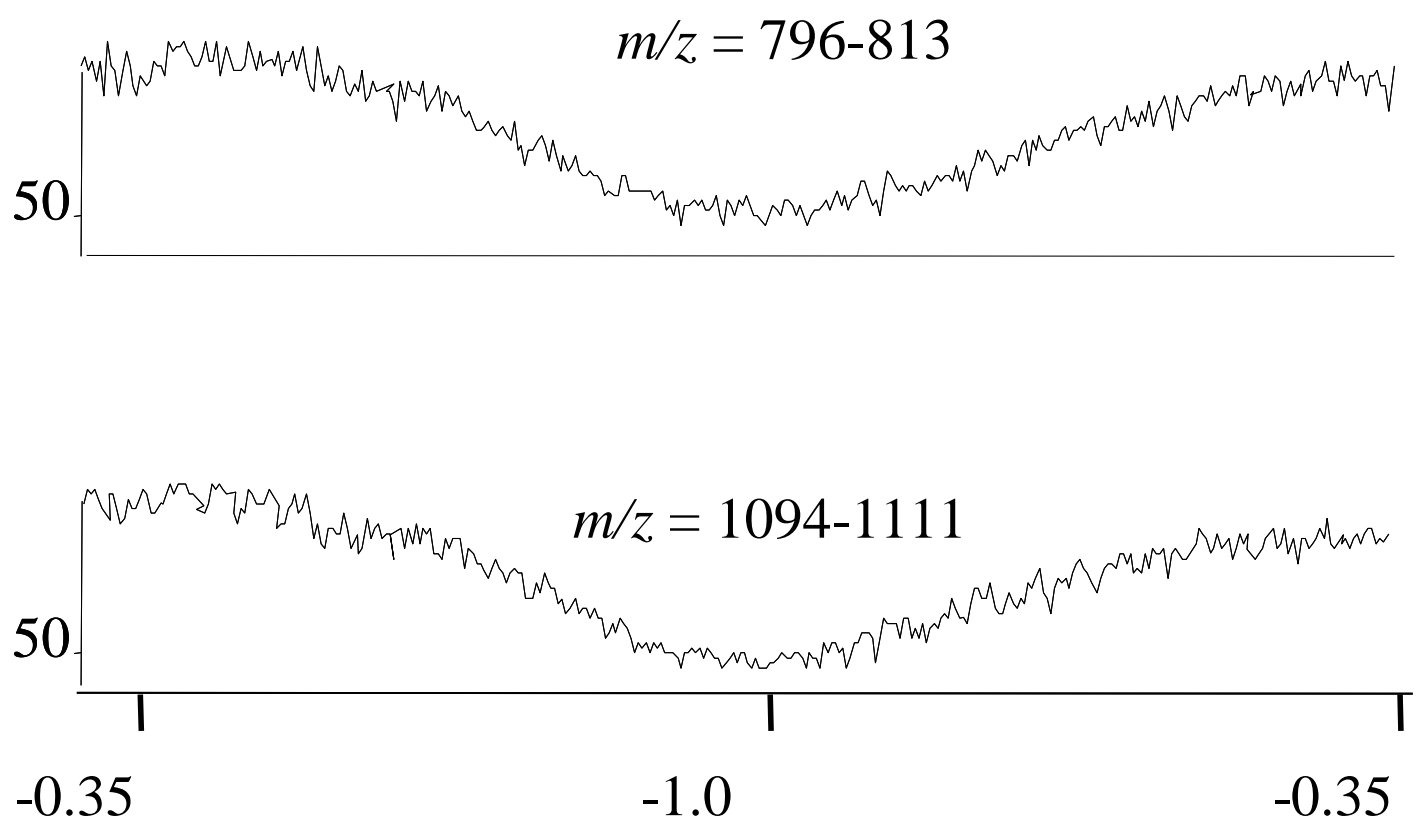
Figure 9

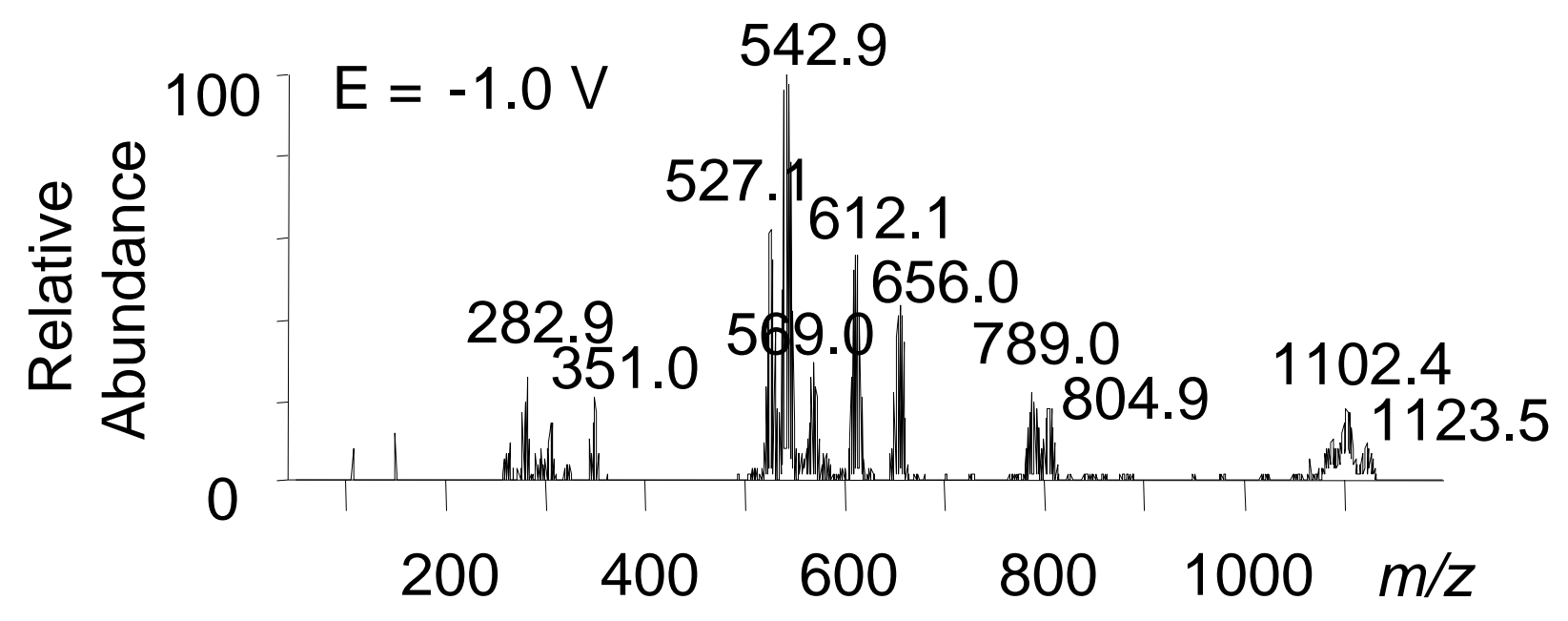


Figure 10

(a) Mononuclear species
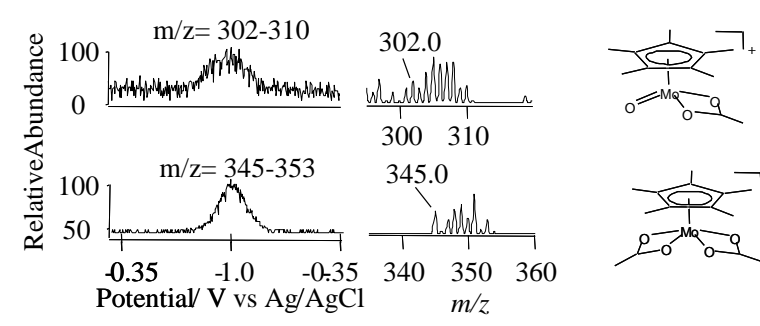

(c) Trinuclear species
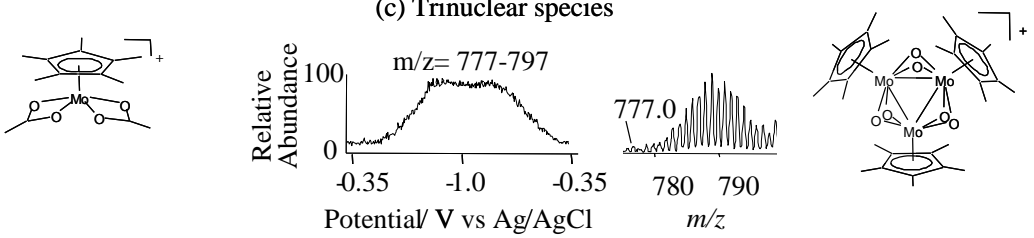

(b) Dinuclear species
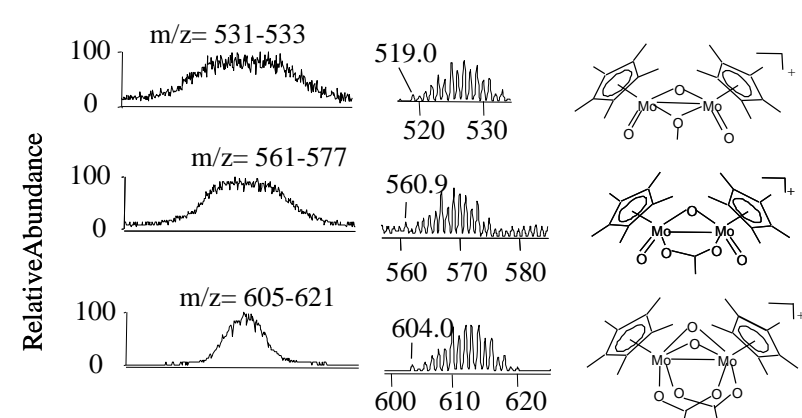

(d) Tetranuclear species
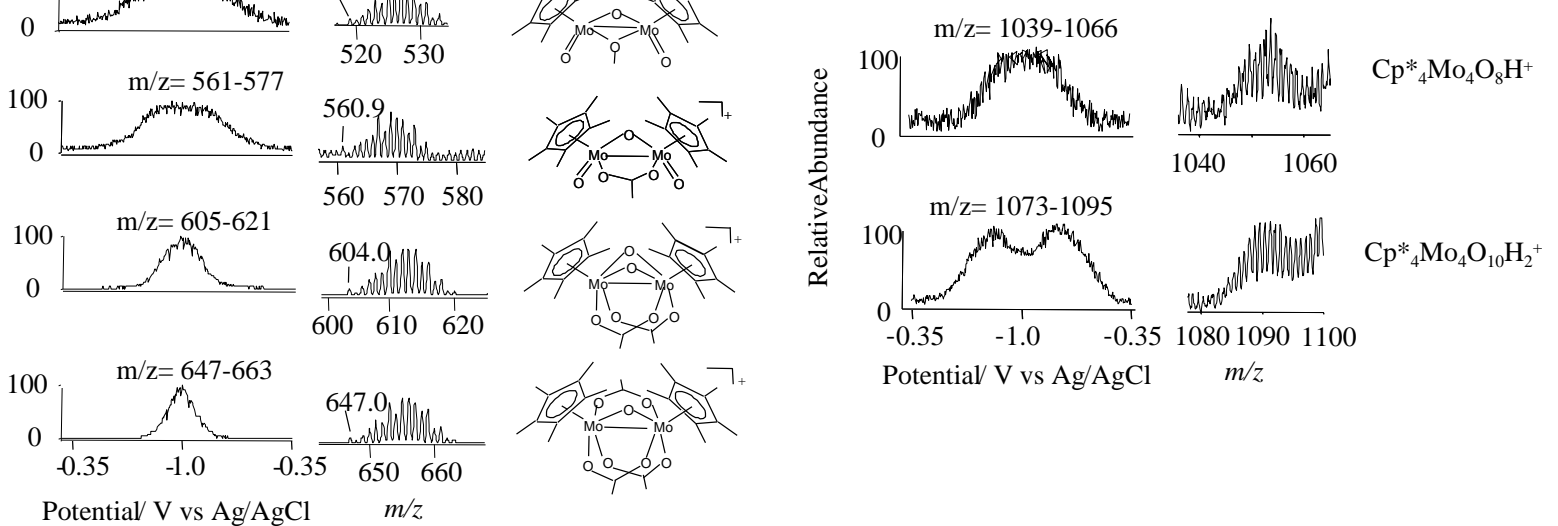

Potential/ V vs $\mathrm{Ag} / \mathrm{AgCl} \mathrm{m} / \mathrm{z}$ 
Scheme 1

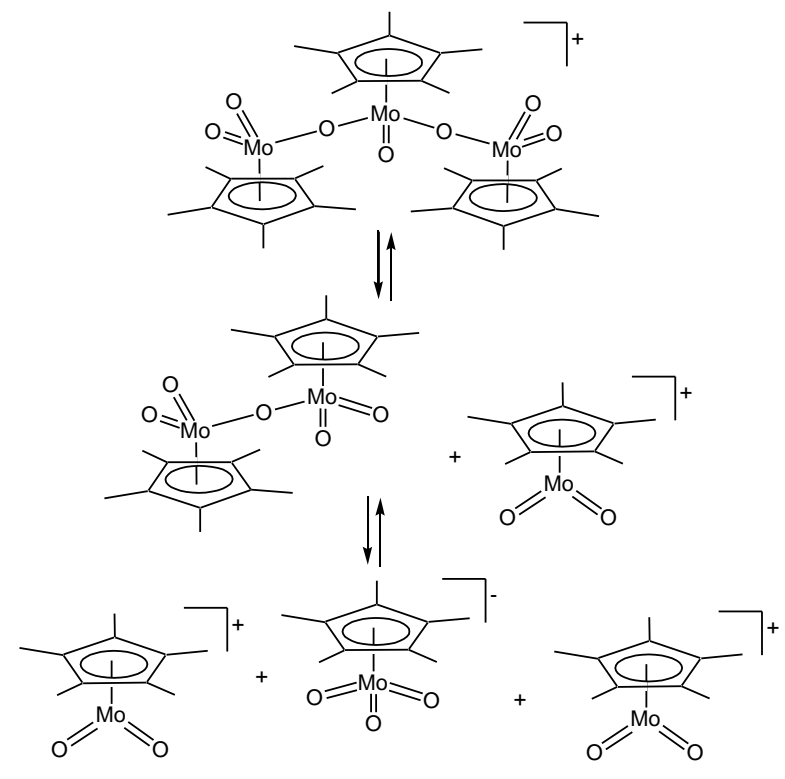


Graphical Content Entry
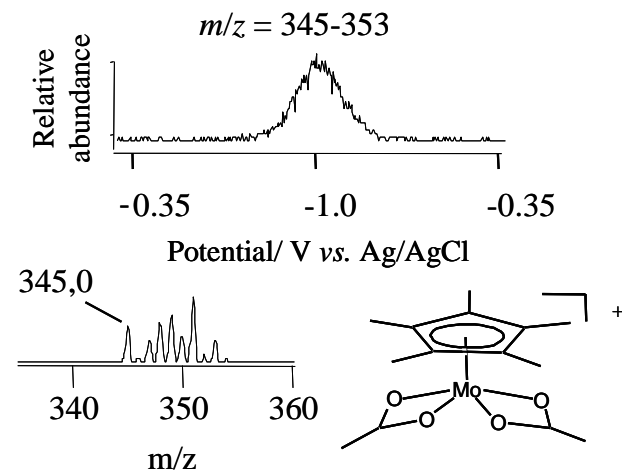

\section{Graphical Abstract}

An electrospray ionisation mass spectrometric analysis coupled on line to a flow through electrochemical cell reveals a rich aqueous reduction chemistry for compound $\mathrm{Cp}_{2}{ }_{2} \mathrm{Mo}_{2} \mathrm{O}_{5}$. 